\title{
ARTICLE \\ The Financing of Small and Medium-Sized Enterprises: An Analysis of the Financing Gap in Brazil
}

\section{Marcelo Godke Veiga ${ }^{1,2,3,4,5}$. Joseph A. McCahery ${ }^{1}$}

Published online: 25 November 2019

(c) The Author(s) 2019

\begin{abstract}
While small and medium-sized enterprises (SMEs) are important for economic growth and employment, they face numerous obstacles in accessing external finance. In this article, we review recent developments in the availability of financing for SMEs in Brazil, focusing on the greater use of equity and debt for SMEs. In assessing the barriers to external financing, we focus on the role of bank characteristics, market structure and variations of interest rate spreads across banks and time. Moreover, as banks retreat from SME financing, we examine the potential for SMEs to seek new sources of financing from private equity and venture capital funds. We examine the changes in the availability of bank loans between 2014 and 2016. By considering demand, we estimate the SME loan gap based on Central Bank and publicly available data. Our results show that the loan gap in Brazil is substantial.
\end{abstract}

Keywords Bank loans · Entrepreneurial financing $\cdot$ Interest rate $\cdot$ SME funding

JEL Classification L21 · L26 · G32

Marcelo Godke Veiga

marcelo@godke.law

Joseph A. McCahery

j.a.mccahery@uvt.nl

1 Tilburg University Law School, Tilburg Law and Economics Center (TILEC), Tilburg,

The Netherlands

2 Fundação Armando Álvares Penteado (FAAP), São Paulo, Brazil

3 Insper-Instituto de Ensino e Pesquisa, São Paulo, Brazil

4 CEU Law School, São Paulo, Brazil

5 University of São Paulo, São Paulo, Brazil 


\section{Introduction}

Enhancing access to financing for small and mid-size enterprises (SMEs) and entrepreneurs is a topic of much interest to policymakers and academics. In Brazil, for example, there are more than 11.5 million companies, employing 56 million individuals and accounting for $27 \%$ of GDP. While SMEs account for $98.5 \%$ of all enterprises and $41 \%$ of total payroll, the sector contributes $20 \%$ to GDP and only $1 \%$ to exports. Indeed, SMEs' important role in the economy has been long recognized; their contributions include job creation, poverty reduction and the achievement of higher levels of economic development. Despite this, small and young firms have typically encountered obstacles to external financing. In fact, first loans to SMEs are continuing to decline in some developing countries and stagnating in countries most affected by the global financial crisis, such as the US, the UK and parts of the European Union (EU). ${ }^{1}$ The consequences of these trends can be observed in the estimated \$5.2 trillion financing gap for SMEs in emerging markets. ${ }^{2}$

Prior literature suggests that SMEs are particularly dependent on credit and cash flow, but they confront limits on borrowing funds because they are small and less diversified and have weaker financial structures. SMEs are more credit-constrained than other firms and, therefore, have lower levels of productivity. Indications that SMEs are financially constrained include payment delays on receivables, declining liquidity, and an increase in SME insolvencies and bankruptcies. Besides the market signals that make SME sector firms unfavorable borrowers, firms find it difficult to always provide high-quality collateral or to ensure transparency with respect to their creditworthiness. $^{3}$

Further, relative to larger firms, the SME sector is extremely sensitive to external market shocks. Some of the main causes are risks associated with small-scale businesses, lack of experience, low productivity, a primary focus on local markets, and the naturally high rate of bankruptcies. However, recent research points out that the SMEs performed well during the crisis and showed a great deal of resilience. ${ }^{4} \mathrm{Nev}-$ ertheless, the higher sensitivity of SMEs to external shocks has affected the supply of short- and long-term financing to SME borrowers. Indeed, data from the Organisation for Economic Co-operation and Development (OECD) show that SMEs in Brazil are currently paying an average interest rate of $20.8 \%$ per year. With firms having to pay higher prices for loans, the less profitable firms are likely to experience higher risks and barriers to growth. Consequently, the significantly higher rates and reduced lending have created many challenges for SMEs and, hence, an important reason to investigate the financing gap that affects the sector.

So, how can policymakers improve the current financial environment to increase lending to SMEs? Cross-country studies show that strong legal and institutional

\footnotetext{
1 OECD (2018).

2 IFC (2017).

3 Ayadi and Gadi (2013).

4 Lopes de Silanes et al. (2015).
} 
environments are critical to SME access to short- and medium-term financing. ${ }^{5}$ In recent years, policymakers and researchers have increasingly begun to explore the differences in SME lending across countries and bank ownership types, as well as strategies to increase the supply of credit to firms. ${ }^{6}$ Two views can be distinguished. The first view examines the differences in institutional and organizational structures and the pricing of bank financing to SMEs. According to this hypothesis, access to external financing is the most critical factor for SMEs. Conversely, according to the second view, significant differences in the supply and demand of financing to SMEs influence the size of the financing gap in debt and equity markets. The implications of this view is that the range of financial products and services is inadequate and incomplete in relation to the needs of SMEs. ${ }^{7}$

In this article, we review recent developments in the availability of financing for SMEs in Brazil, focusing on the greater use of equity and debt. In assessing the barriers to external financing, we initially focus on the role of bank characteristics, market structure and variations in interest rate spreads across banks and time. Next, as banks retreat from SME financing, we focus on the potential for young and innovative firms to seek new sources of financing from private equity and venture capital (VC) funds. We then consider equity financing as an effective alternative to traditional bank financing, particularly when rapid growth is expected. Finally, we examine the changes in availability of bank loans in Brazil between 2014 and 2016. By considering demand, we estimate the SME loan gap based on Central Bank and publicly available data. ${ }^{8} \mathrm{We}$ find that the Brazilian loan gap is substantial and that it grew from $54.29 \%$ in 2014 to $87.5 \%$ in 2016 .

This paper has a number of important policy implications. First, as mentioned, we find evidence that the bank financing gap for SMEs in Brazil is substantial. We suggest that there are several ways that policymakers can improve the flow of debt and equity financing to SMEs. For example, recent work has pointed to enhancing competition in the supply of loans, making it easier for new (including foreign) capital to enter the market. Second, international experience suggests that improved loan support and guarantees, as well as the promotion of non-bank financing channels, are likely to play an important role as alternative sources of financing for SMEs.

The remainder of the paper is organized as follows. Section 2 briefly reviews the role that SMEs play in Brazil's economy. Section 3 provides evidence on the characteristics of the banking and capital markets and the role of SME financing. Section 4 analyzes the estimated loan gap. Section 5 concludes.

\footnotetext{
5 Beck et al. (2011).

${ }^{6}$ IFC (2010); Ayyagari et al. (2011); Beck and Demirguc-Kunt (2006).

7 Fenwick et al. (2018).

${ }^{8}$ See the Brazilian Institute of Geography and Statistics (IBGE-Instituto Brasileiro de Geofrafia e Estatistica), and the Brazilian Service to Support Micro and Small Enterprises (SEBRAE-Servico de Apoio as Micro e Pequenas Empresas).
} 


\section{Background}

In this section, we begin with a review of the theories motivating our analysis of the financing of SMEs. Next, we focus on the factors influencing the allocation of bank loans to small businesses. We then discuss the literature on alternatives to traditional business lending to SMEs.

\subsection{External Funding of SMEs}

In recent years, empirical studies have focused on a number of strategies that have been demonstrated to alleviate credit rationing. In general, these strategies focus on: (1) an effective legal and regulatory framework; (2) a loan guarantee system to reduce reliance on collateral; and (3) alternative financing instruments.

First, it is clear that the presence of information asymmetries and principal/agent problems may induce sellers of financial services to offer products that, due to monitoring problems, leave potential borrowers without access to credit. ${ }^{9}$ Some of the early work on this issue emphasized that lenders have gained from looking at the creditworthiness and reputation of the founders or owners to distinguish good from bad borrowers. ${ }^{10}$ From this perspective, the absence of an adequate credit history and high rates of default will likely lead to credit denials. Furthermore, banks' local network ties and relationships play an important role in reducing the uncertainties and mitigated some of the risk of opportunism associated with bank lending to SMEs. Moreover, this literature has emphasized how enabling environmental initiatives may have actually reduced information asymmetries by establishing effective monitoring techniques.

The second mechanism, the use of collateral, gives the SME with a serious credit problem an incentive to repay the loan. Collateral may prove to be an efficient mechanism to screen bad borrowers, as those carrying lower risk are usually more willing to provide greater levels of collateral (as they have no intention of defaulting or increasing the risk of their operations). However, one of the main problems restricting SME borrowing is the lack of sufficient collateral. Consequently, high-risk borrowers are usually more open to the idea of paying higher interest rates, as long as they do not have to provide higher levels of collateral (as they may have the intention of defaulting or increasing the risk of their operations).

Research suggests that if collateral is not available, a credit guarantee system can provide credit support and help SMEs with two separate problems. First, it may reduce the risk premium charged by banks. Second, the presence of a guarantee may actually help the small firm qualify for the loan under the bank's loan policy. Indeed, the absence of an adequate guarantee program in markets with inadequate transparency (namely, developing countries such as Brazil) may put the very existence of the market at risk, and certain efforts may be undertaken to deal with this issue. ${ }^{11}$ In

\footnotetext{
9 Beck and Demirguc-Kunt (2006).

10 Berger and Udell (1998).

11 Akerlof (1970).
} 
order to resolve this problem, governments, such as those of Germany, Italy, Japan, Korea, UK and US, have intervened by providing guarantees to banks that lend money to SMEs, thus increasing the amount of bank financing available to smaller companies. ${ }^{12}$ Thus, a credit guarantee system that offsets the reduced reliability of nonaudited financial statements arguably improves access to credit and loan terms. Governments tend to invest in loan guarantee programs because they address the market imperfections that cause credit restrictions to SMEs, and they spur innovation in the SME sector. ${ }^{13}$

Third, as banks retreat from SME financing, some segments of the SME sector continue to face difficulties in securing access to financing. On the one hand, the growth of alternative online lending has made it easier for low-income businesses and small, young firms to secure credit without collateral or government support. ${ }^{14}$ This has helped these lenders in the United States, for example, to become important providers of capital to such businesses while also helping to bridge the funding gap in the SME credit market. ${ }^{15}$ On the other hand, the financing problems faced by SMEs in developing economies may be even more pervasive. ${ }^{16}$ Indeed, there appears to exist a 'missing middle' (the lack of a large number of mid-size companies), while a restricted number of large companies exist side-by-side with a large quantity of smaller ones. This phenomenon stems mostly from a combination of inadequate (rigid) regulation (where firms prefer to stay small so that they shun the burdens of full compliance) and certain structural and market characteristics (low level of development, underdeveloped markets, poor demand and hostile business environment). Indeed, smaller companies may prefer to stay small than to grow and attract enforcement. Also, financial systems in developing markets are likely to be more highly regulated and closed, with few reform measures or effective supervision. Hence, SMEs face greater challenges and are more adversely affected in emerging countries, with a larger number of firms operating informally or with restricted access to financing.

Finally, another important factor affecting the number of loans granted to SMEs is bank size and control. ${ }^{17}$ Smaller (local) banks with low-scale operations tend to develop long-term relationships with borrowers, which is positive for smaller firms (as they are normally more opaque than larger companies). ${ }^{18}$ Such relationships may allow banks to gather more information to be used in the decision-making process to grant a loan and to define the terms of the credit. ${ }^{19}$ Consequently, SMEs with longterm relationships tend to pay lower interest rates and provide less collateral. Also,

\footnotetext{
12 OECD (2006).

13 See OECD (2018).

14 Kgoroeadira et al. (2018).

15 Usman et al. (2016).

16 IMF (2019).

17 Key factors in the Brazilian banking market are the role of large banks (including state-owned or state-controlled banks) and the high level of concentration.

18 OECD (2006).

19 Berger and Udell (1995); Padilla and Pagano (1997).
} 
small firms tend to restrict the number of banks they use, normally meeting their working capital needs with a single lender.

In summary, SMEs tend to prefer working with smaller banks, which may pay more attention to meeting their needs. To further explore the impact of financial constraints on SMEs, we examine their contribution to innovation and economic growth in Brazil.

\section{Small and Medium-Sized Enterprises in Brazil}

In this section, we briefly describe different criteria used to measure and define SMEs. Also, we review the status of debt and equity markets and consequences for small firms.

\subsection{Small and Medium-Sized Enterprises: Their Contribution to the Economy}

Numerous studies have explored alternative criteria for firm size. The term 'small and medium-sized enterprise' used here has no agreed-upon international definition. Thus, the definition of an SME varies across diverse countries and sectors. To be sure, SMEs can be defined in terms of sales volume, number of employees, or level of investment. Moreover, many countries use different criteria to measure firm size. For example, in Brazil, various organizations, such as the Institute for the Support of Micro and Small Firms (SEBRAE), have adopted criteria for firm size based on the number of employees in the firm. In contrast, both the Brazilian Development Bank (BNDES) and Brazilian policymakers use sales volume as their criterion. Brazil defines SMEs using three broad categories: micro-proprietorships, micro-enterprises and small enterprises. Micro proprietorships are defined as companies with gross revenues not exceeding BRL81,000. In contrast, micro enterprises have gross revenues not exceeding BRL360,000, while small enterprises have revenues not exceeding BRL4,800,000. The majority of SMEs shown in Table 1 are micro and small enterprises. ${ }^{20}$ These data are consistent with earlier studies that show the presence of a large number of micro-enterprises and small firms in developing economies.

Figure 1 shows the share of the sectors with the largest share of SMEs. In terms of the three categories of SMEs, they are likely to play different roles in the economy due to the access of information and other resources. The figure shows the majority of SMEs are involved in commerce, industry, food and lodging, services and construction.

Another factor likely to influence the growth of SMEs concerns the effect of burdens created by bureaucracy and administrative procedures. In Brazil, this concern initially led 11.5 million companies to adopt the special tax regime for micro and small businesses provided under Complementary Law No. 123/06 ('Simples

${ }^{20}$ See http://empresometro.cnc.org.br/Estatisticas. 
Table 1 Total number of firms in Brazil. Source: National Confederation of Commerce [see http://empre sometro.cnc.org.br/Estatisticas (visited on 20 March 2017)]

\begin{tabular}{llll}
\hline Number of firms in Brazil & & & \\
\hline Year & Active companies (mil.) & SMEs (mil.) & SMEs (\%) \\
\hline 2017 (March) & $17,924,540$ & $16,059,645$ & 89.59 \\
\hline
\end{tabular}

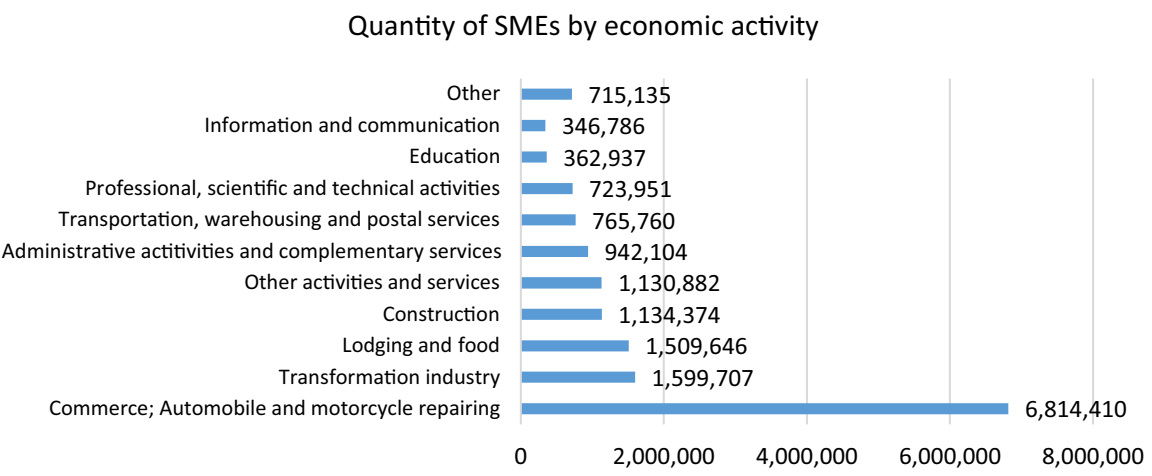

Fig. 1 Number of SMEs-economic activity. Source: National Confederation of Commerce [see http:// empresometro.cnc.org.br/Estatisticas (visited on 20 March 2017)]

Nacional' program). ${ }^{21}$ For the period 2007-2011, the effects of the tax burden reduction resulted in a payroll increase of $25 \%$ and a $21.5 \%$ increase in jobs for firms participating in the Simples Nacional program (with a R \$2.4 M threshold). ${ }^{22}$ This highlights the fact that such simplification strategies are particularly important for the growth of SMEs operating in developing counties with high tax compliance costs. Note that the recent introduction of a new law, MP/881/2019, in April 2019 is another attempt by policymakers to reduce the costs for new and small firms to start a company and to make it easier to obtain the necessary permits.

Our discussion so far has focused on the perceived factors impacting the growth of SMEs. ${ }^{23}$ So the main concern is not to simply reduce the regulatory burden, but to effectively address the institutional impediments to the creation and growth of innovative SMEs. Prior studies report that SMEs with a broad diversity of strategies face obstacles to innovation. Where these obstacles are likely to play an important role, a set of broad-based reforms and methods may curtail the learning and innovation obstacles in order to achieve growth of SMEs in high priority areas, such as knowledge-intensive industries. ${ }^{24}$

${ }^{21}$ Conceição Canozzi et al. (2018).

${ }^{22}$ Franco et al. (2017).

23 European Economic and Social Committee (2017).

24 OECD (2018). 
Furthermore, it has been argued that a relationship exists between the age and the type of companies that get involved in innovation. In Brazil, between 2011 and 2015, approximately 4.55 million companies with at least ten employees were approximately 11 years old. An analysis of the relative size of companies highlights the fact that smaller companies are less likely to survive, particularly in the Brazilian market. Indeed, out of all the companies existing at the beginning of $2011,67.1 \%$ of firms with ten or more employees were still active at the end of 2015, compared with $57.8 \%$ of firms having between one and nine employees and $31.8 \%$ of firms with zero employees. That said, the evidence presented in this paper shows that there is a clear relation between the number of employees/size of the company and longevity. In short, the Brazilian experience suggests that smaller companies have a lower probability of survival than larger ones. Figure 2 also displays that there has been a downward trend in the survival rate of firms, with fewer than $37.8 \%$ still in existence at the end of 2015 .

One may expect that successful SMEs have the ability to produce innovative products and services. ${ }^{25}$ Indeed, a key challenge for governments is to promote policies associated with the development of inputs needed to produce innovations and exploit long-term outputs. An important consequence of SMEs' innovative role is public policy support for programs linked to the development of skills and innovative activity. This type of policy focus to increase the role of SMEs in relation to innovation is seen as crucial in many developing economies, such as Brazil's. Yet broad-based government policies to enhance the growth and development of innovative SMEs may involve considerable risk. First, there are different types of entrepreneurial SMEs that require a tailored mix of non-financial and financial policies to shape the outcome and behavior of these firms. ${ }^{26}$ Second, there is a question that pertains to the ability of policymakers to identify high growth SMEs ex ante. ${ }^{27}$

To get a better sense of innovative SMEs in Brazil, Fig. 3 shows that of the firms with at least ten employees, approximately $36 \%$ were involved in some level of innovative activity (either their processes or their products) between 2012 and 2014. These data confirm earlier studies that the SME performance in terms of innovations significantly lags behind other countries. ${ }^{28}$ But, as noted above, it is expected that the recent easing of licensing and other regulatory requirements may also help encourage innovative activities by SMEs.

In order to determine the financing options for SMEs, in the next section, we will examine alternative sources of debt and equity available in Brazil.

\subsection{Debt and Equity Markets in Brazil}

Bank loans and lines of credit remain the main sources of external financing for SMEs. The bank-lending channel was weakened during the financial crisis, as evidenced by banks' reduced lending capacity and the increase in interest rates on new loans. The

\footnotetext{
25 BCG (2017).

26 OECD (2018); McCann and Ortega-Argilés (2016).

27 InfoDev/World Bank (2016).

28 Melo et al. (2015).
} 


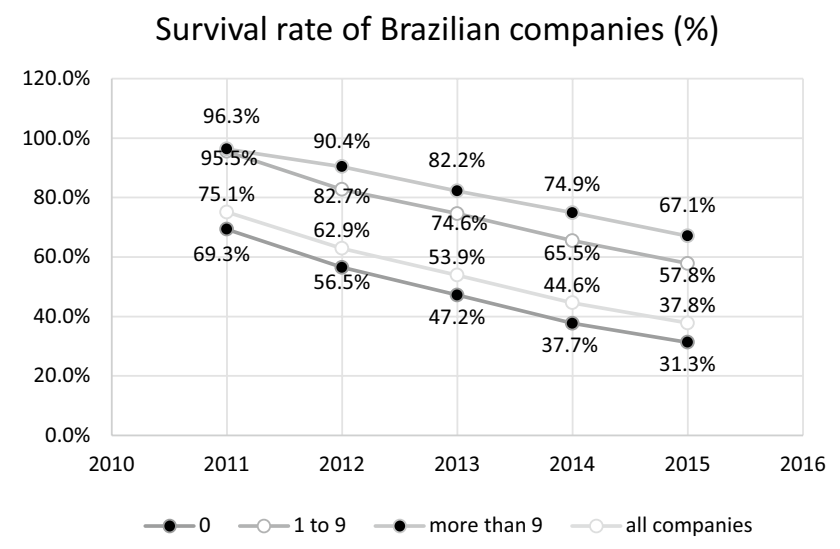

Fig. 2 Survival rate of Brazilian companies (\%). Source: IBGE (2017)

\section{$\%$ of innovative firms}

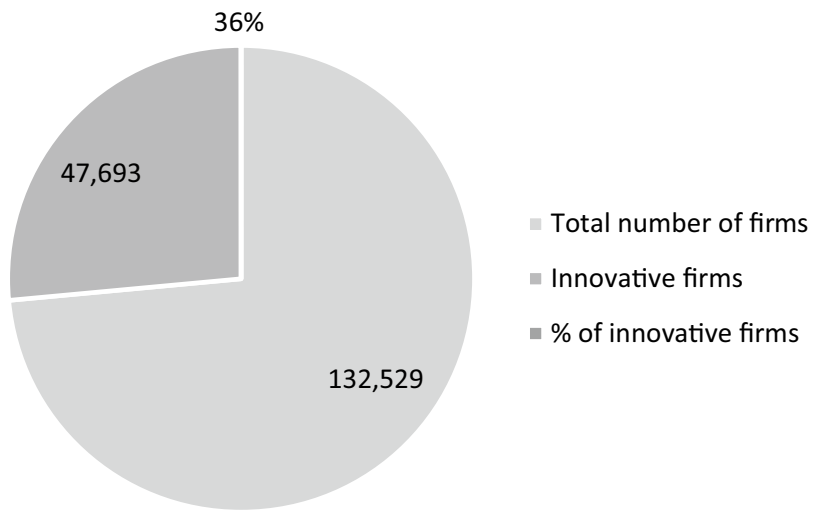

Fig. $3 \%$ of innovative firms in Brazil. Source: IBGE (2014)

higher sensitivity to external shocks led to changes in the supply of short- and longterm financing to SME borrowers. Data from the Central Bank of Brazil show that, as of February 2016, more than 173 financial institutions were approved to conduct bankclearing operations in the country (see Fig. 4). There are also striking differences across regions in terms of total banking-sector assets. Notably, most financial institutions are headquartered in the State of São Paulo, the richest of the Brazilian federation. This number includes foreign banks doing business in Brazil, as well as state-owned or statecontrolled banks. This number is not large by any standard, mainly when considering that Brazil has the 9th largest economy and 6th largest population in the world. Yet the financial system in Brazil cannot be considered small and is mostly bank-oriented. ${ }^{29}$

${ }^{29}$ Belaisch (2003). 


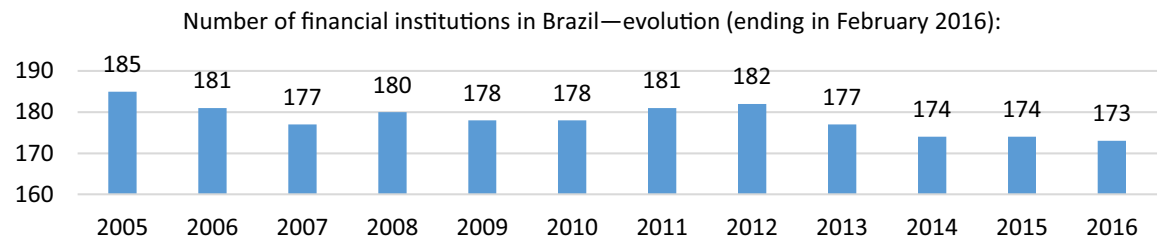

Fig. 4 Number of financial institutions in Brazil—evolution. Source: Febraban-Federação Brasileira de Bancos (2015)

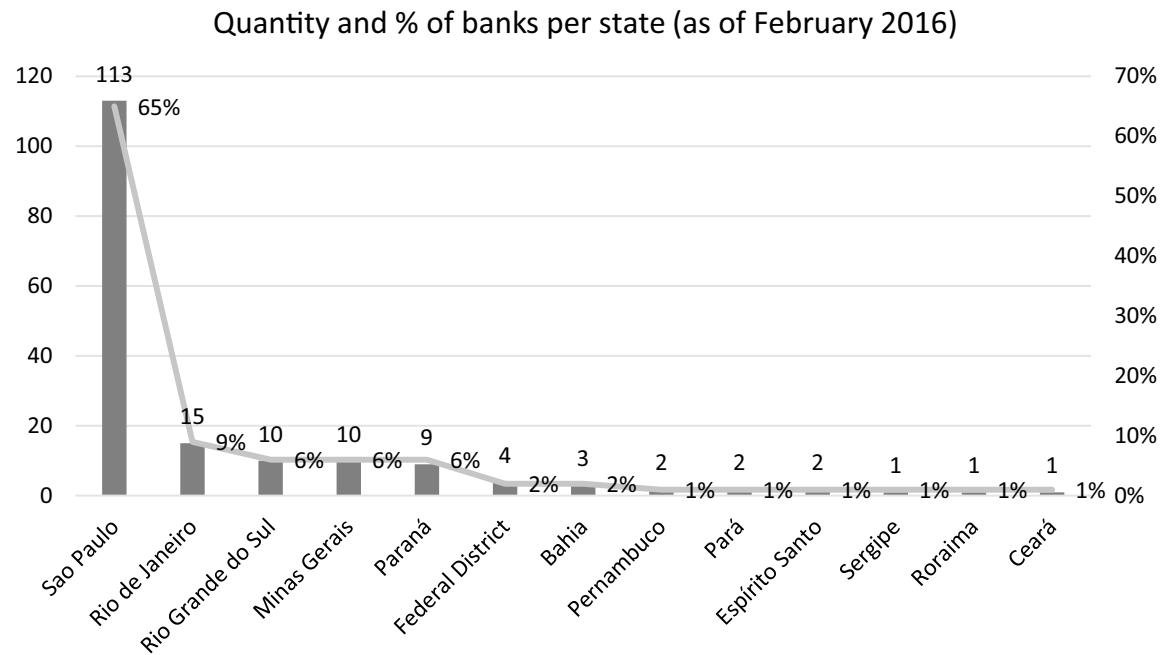

Fig. 5 Number and \% of banks per state. Source: Febraban—Federação Brasileira de Bancos (2015)

In fact, many parts of the country are largely without adequate bank-branch coverage. Significantly, even in the most populated areas, approximately only half of the potential market is actually serviced by banks. ${ }^{30}$ Figure 5 shows that most banks are located in the Southeastern ${ }^{31}$ and Southern ${ }^{32}$ states. Moreover, more than half of the Brazilian states have no banks headquartered in their jurisdiction, suggesting a greater overall need for banks.

With a population of approximately 206 million people distributed across 5570 municipalities, ${ }^{33}$ Brazil still has relatively few bank branches. Moreover, their distribution varies significantly across states, and the great majority of branches are located in the states of São Paulo and Rio de Janeiro (see Fig. 6).

\footnotetext{
30 Belaisch (2003).

31 The 'Southeast Region' of Brazil comprises the states of São Paulo, Rio de Janeiro, Minas Gerais and Espírito Santo.

32 The 'South Region' of Brazil comprises the states of Paraná, Santa Caratarína and Rio Grande do Sul.

33 See http://www.ibge.gov.br/home/geociencias/cartografia/default_territ_area.shtm (visited on 23 March 2017).
} 
Quantity and \% of bank branches in Brazil (as of February 2016) - per state

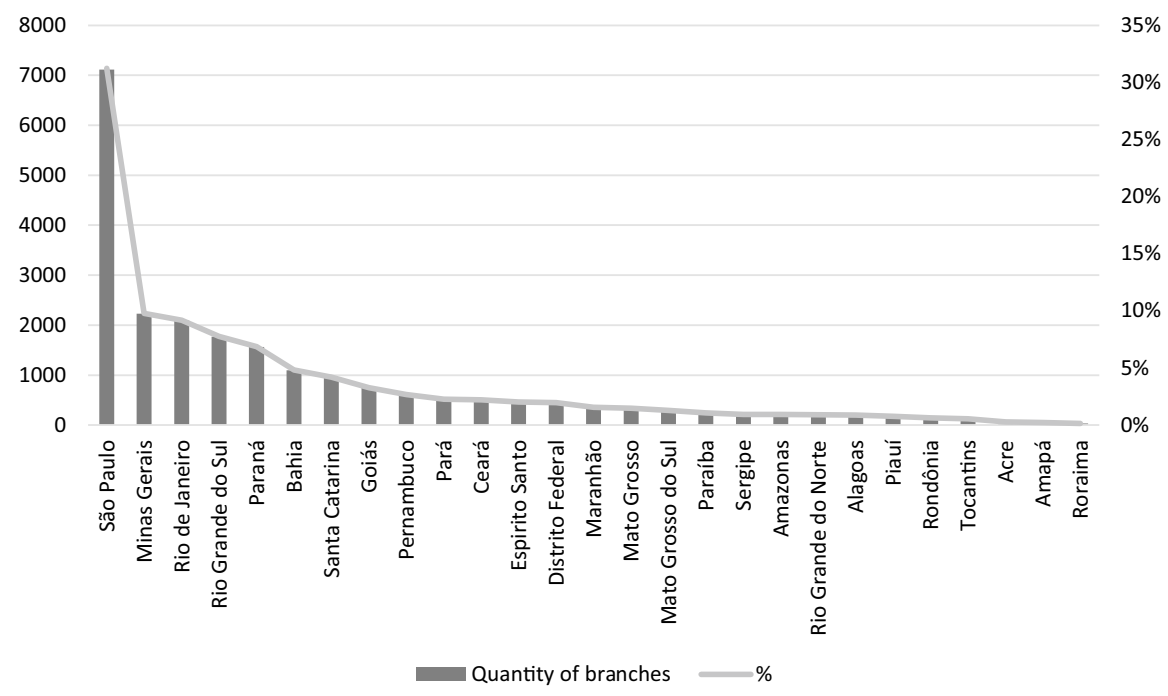

Fig.6 Quantity and \% of bank branches in Brazil, per state. Source: Febraban-Federação Brasileira de Bancos (2015)

Quantity and \% of banking service stations in Brazil

(as of February 2016) - per state

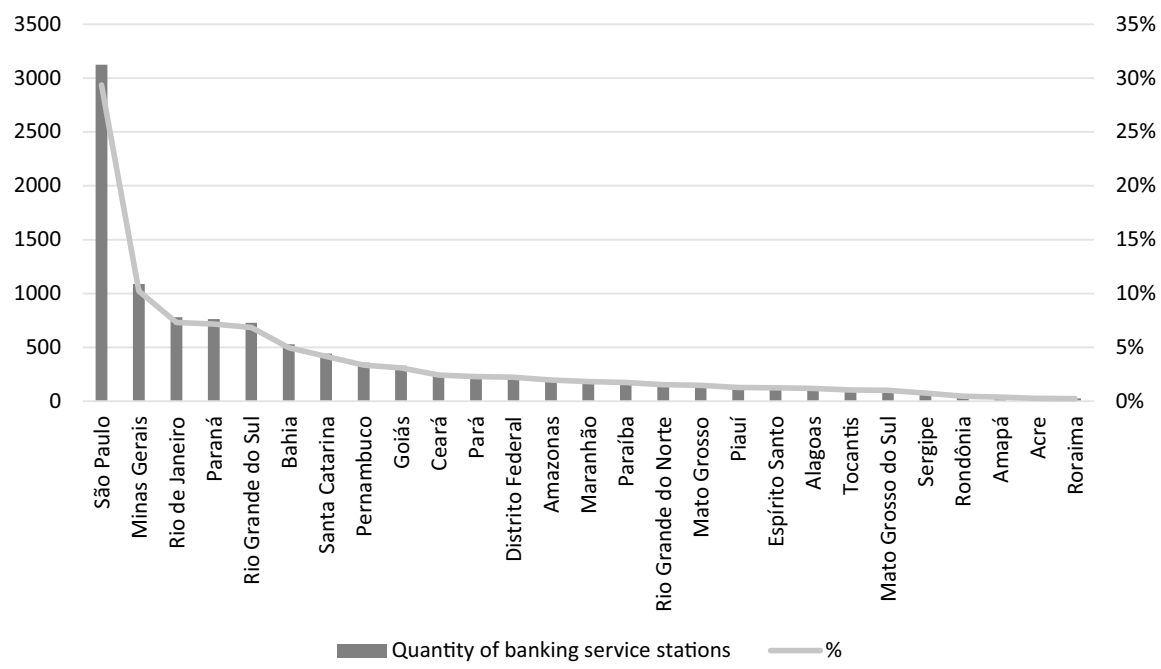

Fig. 7 Quantity and \% of banking service stations. Source: Febraban-Federação Brasileira de Bancos (2015) 


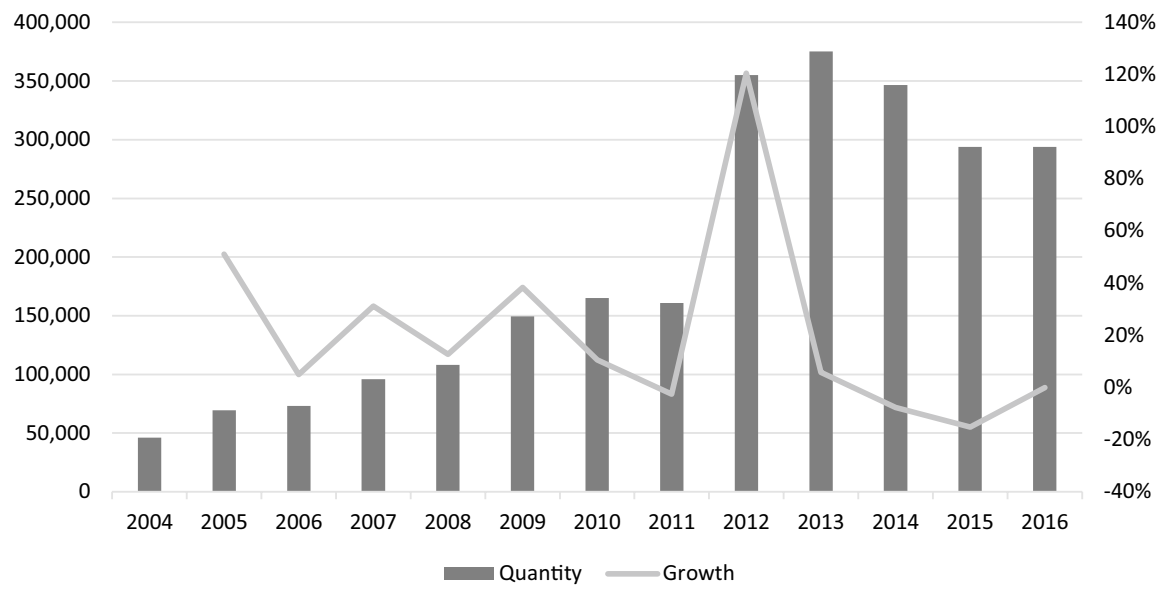

Fig. 8 Number of 'bank correspondents' in Brazil (as of February 2016). Source: Febraban—Federação Brasileira de Bancos (2015)

Although there are 26 states and a Federal District in Brazil, 16 have fewer than 500 bank branches. Starting from a very low base, the population would seem to be seriously underbanked if no alternatives were available. However, a different approach, based on Brazilian regulation, has attempted to address this problem by allowing banks to create banking service stations. As a result, there are now 10,645 banking service stations in Brazil, most of which are in São Paulo (3124). As the case of banks, it is worth noting that, as Fig. 7 shows, there are fewer than 500 banking service stations in the other states.

As banking service stations are limited and under-resourced, 'bank correspondents' may often provide an alternative. ${ }^{34}$ While bank correspondents are not financial institutions, they can enter into a contractual relationship with a full-fledged bank to offer a wider range of financial products and services. On the supply side, the mere existence of bank correspondents is not equivalent to a larger number of banks or more credit being available. To be sure, there is a definite potential to expand the number of bank correspondents, as evidenced by increased numbers until 2013 (reaching a total of 375,315), but then a sharp drop reduced the number in February 2016 (see Fig. 8).

In recent years, there has been growing concern that the Brazilian banking market is extremely concentrated. ${ }^{35}$ We see that, as of December 2016, the four largest

\footnotetext{
${ }^{34}$ According to National Monetary Council Resolution No. 3954, dated 24 February 2011, bank correspondents are not financial institutions per se. They provide limited services to financial institutions and cannot take deposits or advance loans. Their services include gathering and forwarding (to the contracting financial institution) applications for opening bank accounts, credit cards, loans and financial leasing, receiving bill payments and carrying out foreign exchange transactions.

35 Tabak, Fazio and Cajueiro (2010).
} 
banks-Banco do Brasil, Itaú, Caixa Econômica Federal and Bradesco ${ }^{36}$ - together, held $72.70 \%$ of all banking assets, $78.48 \%$ of all deposits and $78.99 \%$ of all credit transactions in Brazil, compared with $52.58 \%, 59.32 \%$, and $54.67 \%$, respectively, in December 2007.

\subsection{Market Concentration}

On the whole, this represents a steep and important increase in bank concentration and is likely to have a strong influence on interest rates across the market (see Fig. 9). In particular, the concentration in the Brazilian banking system plays an important role in the SME financing gap. In practice, smaller (local) banks with low-scale operations tend to develop long-term relationships with borrowers, which may facilitate greater availability of loans. ${ }^{37}$ As noted above, evidence suggests that closer relationships with creditors is an important mechanism to reduce information asymmetries. Consequently, the information gained may lead banks to offer lower rates. ${ }^{38}$ However, larger banks have a more difficult time developing long-lasting relationships with SMEs, as loan officers constantly rotate, and merged banks (which makes them grow bigger) may shut down offices and transfer employees from the location where the firm typically obtains its bank financing. ${ }^{39}$ Also, larger banks tend to be more focused on transactions than on long-term relationships, preferring a smaller number of larger deals to a large number of loans. We note that banks undergoing growth tend to devote a smaller percentage of their portfolios to small firms, which suggests that the greater the consolidation, the lower the percentage of credit that will be available to SMEs. ${ }^{40}$ In addition, we can observe a similar influence on financial institutions that have SMEs as borrowers.

Perhaps the most prominent feature of the banking sector is the high levels of banking spreads and interest rates charged by financial institutions. In terms of the business environment, high spreads have negatively impacted the expansion of credit and economic growth. ${ }^{41}$ Specifically, the average annual bank interest rate was $23.7 \%$ for all types of transactions available in the Brazilian credit markets in 2014.

In terms of market segmentation, the Central Bank of Brazil divides the credit markets into (i) directed ${ }^{42}$ and (ii) non-directed ${ }^{43}$ transactions. For directed credit transactions, which include government and other subsidized lending, the average interest rate was $7.8 \%$, whereas the non-directed average rate was $37.3 \% .{ }^{44}$ Brazilian companies face significantly higher interest rates than their counterparts around the

\footnotetext{
36 Banco do Brasil and Caixa Econômica Federal are state controlled, while Itaú and Bradesco are not.

37 Berger and Udell (1995).

38 Petersen and Rajan (1995); Harhoff and Korting (1998).

39 OECD (2006).

40 Berger and Udell (1995).

41 Fiche (2015).

42 The Central Bank of Brazil uses the expression 'crédito direcionado.'

43 The Central Bank of Brazil uses the expression 'recursos livres.'

44 Banco Central do Brasil (2014).
} 


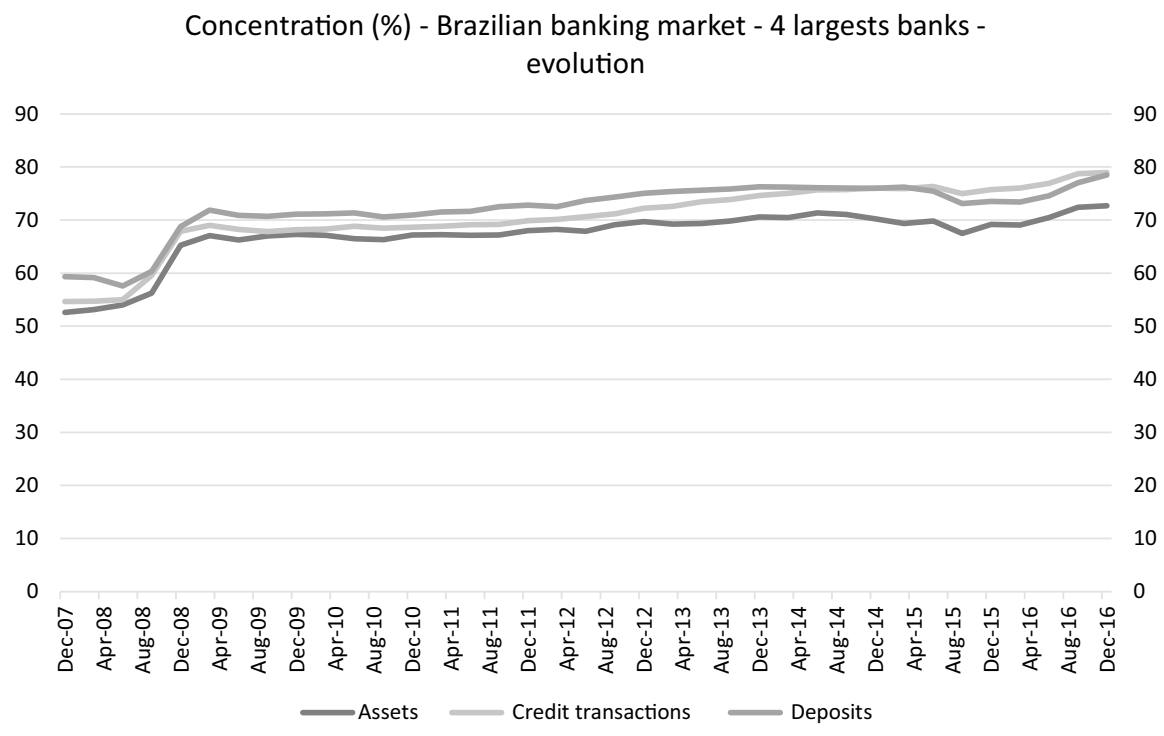

Fig. 9 Concentration in the Brazilian banking market (\%)—four largest banks. Source: Banco Central do Brasil (2017)

world. ${ }^{45}$ Figure 10 shows the range of interest rates in Brazil from 17 to 23 August 2017. For example, the rates charged by banks for certain types of business lending, such as short-term working capital financing, were extremely high, with a fixed interest rate between 10.8 and $83.7 \%$.

Table 2 show the differences in the average annual interest rates on a variety of loans by the four largest Brazilian banks: Banco do Brasil, Itaú, Caixa Econômica Federal and Bradesco.

In this context, a number of scholars have challenged the existence of a competitive market. For example, some critics argue that the Brazilian banking market operates as an oligopoly, and banks have few incentives to improve market efficiency. ${ }^{46}$ Others claimed that the Bertrand oligopoly model closely resembles the banking market in Brazil. On the other hand, Fiche raises similar concerns that spreads in Brazil are higher than in other countries. ${ }^{47}$ However, he finds no support for the view that higher concentrations in the banking systems directly affect the rates offered to firms seeking financing. In sum, Fiche's study is consistent with studies that have suggested bank system concentration does not explain market power. ${ }^{48}$

\footnotetext{
45 OECD (2019).

46 Belaisch (2003).

47 Fiche (2015).

48 Claessens and Laeven (2004).
} 


\section{Bank interest rates}

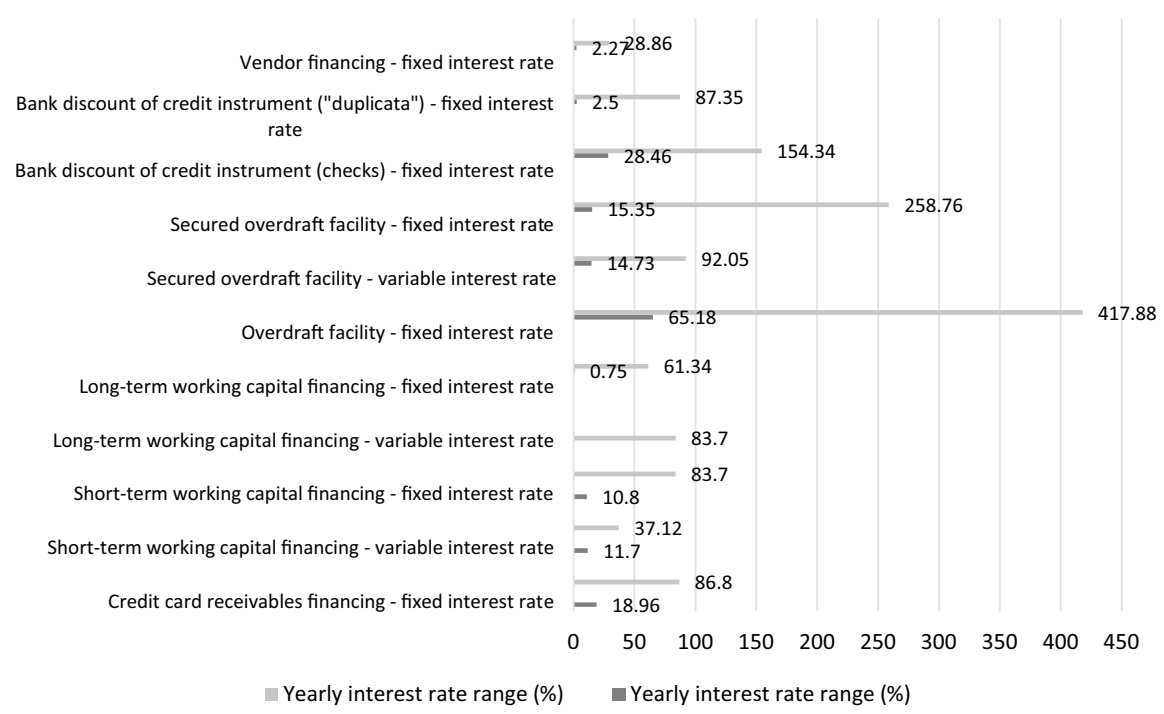

Fig. 10 Bank interest rates for businesses-yearly \%-range (lowest-highest \%) —Sample period: 17 August-23 August 2017. Source: Banco Central do Brasil (2017)

Another dimension of bank market power has to do with borrower discouragement. ${ }^{49}$ A large empirical literature on the relation between bank concentration and borrower discouragement has emerged in recent years. For example, small firms in developed economies, like the US and Europe, are less likely to be discouraged as bank market power increases. ${ }^{50}$ Examining banking relationships, Han et al. find evidence that relationships provide banks with better performance on borrower screening, which in turn reduces screening errors and discouraged borrowers. In contrast, other studies focus on the concern that borrowers might suffer hold up problems in a relationship with their bank and reduce the demand for relationship lending as bank market power increases. ${ }^{51}$ Also, prior literature considering the impact of bank concentration in developing economies find that bank concentration limits SMEs' access to external finance. ${ }^{52}$

Figure 11 below provides a summary of survey questions describing the response to SMEs applying for a bank loan between 2015 and 2017. As such, we would expect that the risk of discouragement would be high for SMEs seeking short term external financing.

\footnotetext{
49 Kon and Storey (2003); Chakravarty and Xiang (2013); Cole and Sokolyk (2016).

50 Han et al. (2009); Mac an Bhaird et al. (2016).

51 Berger et al. (2008).

52 Love and Martinez Peria (2015).
} 
Table 2 Bank interest rates for businesses-four largest Brazilian banks-yearly \%—range (lowesthighest \%)—sample period: 17 August-23 August 2017 (according to the Central Bank of Brazil, it is unlikely that the four banks will participate in all transactions due to market preferences or a failure to properly record transactions). Source: Central Bank of Brazil (http://www.bcb.gov.br/pt-br/\#!/c/txjuros/1, visited on 13 July 2018)

\begin{tabular}{|c|c|c|}
\hline Type of financing & Financial institution & Yearly rate $(\%)$ \\
\hline \multirow[t]{3}{*}{ Credit card receivables financing-fixed interest rate } & Itau & 20.86 \\
\hline & Bradesco & 25.43 \\
\hline & Banco do Brasil & 38.14 \\
\hline \multirow[t]{3}{*}{ Short-term working capital financing-variable interest rate } & Banco do Brasil & 14.92 \\
\hline & Itau & 19.75 \\
\hline & Bradesco & 19.98 \\
\hline \multirow[t]{3}{*}{ Short-term working capital financing-fixed interest rate } & Itau & 27.07 \\
\hline & Bradesco & 31.66 \\
\hline & Caixa Econômica Federal & 49.51 \\
\hline \multirow[t]{2}{*}{ Long-term working capital financing-variable interest rate } & Banco do Brasil & 15.29 \\
\hline & Caixa Econômica Federal & 17.88 \\
\hline \multirow[t]{4}{*}{ Long-term working capital financing-fixed interest rate } & Banco do Brasil & 18.99 \\
\hline & Itau & 23.97 \\
\hline & Caixa Econômica Federal & 28.83 \\
\hline & Bradesco & 29.5 \\
\hline \multirow[t]{4}{*}{ Overdraft facility - fixed interest rate } & Itau & 352.81 \\
\hline & Bradesco & 354.26 \\
\hline & Banco do Brasil & 358.01 \\
\hline & Caixa Econômica Federal & 368.18 \\
\hline \multirow[t]{4}{*}{ Secured overdraft facility — variable interest rate } & Bradesco & 24.5 \\
\hline & Itau & 24.79 \\
\hline & Caixa Econômica Federal & 26.97 \\
\hline & Banco do Brasil & 26.99 \\
\hline \multirow[t]{3}{*}{ Secured overdraft facility-fixed interest rate } & Banco do Brasil & 41.89 \\
\hline & Itau & 54.03 \\
\hline & Bradesco & 71.59 \\
\hline \multirow{4}{*}{$\begin{array}{l}\text { Bank discount of credit instrument (checks)—fixed interest } \\
\text { rate }\end{array}$} & Bradesco & 39.52 \\
\hline & Banco do Brasil & 41.78 \\
\hline & Itau & 42.12 \\
\hline & Caixa Econômica Federal & 48.16 \\
\hline \multirow{4}{*}{$\begin{array}{l}\text { Bank discount of credit instrument ('duplicata')—fixed } \\
\text { interest rate }\end{array}$} & Bradesco & 28.39 \\
\hline & Banco do Brasil & 28.77 \\
\hline & Itau & 28.88 \\
\hline & Caixa Econômica Federal & 51.19 \\
\hline \multirow[t]{3}{*}{ Vendor financing-fixed interest rate } & Itau & 14.81 \\
\hline & Banco do Brasil & 16.65 \\
\hline & Bradesco & 19.95 \\
\hline
\end{tabular}


In the last 6 months, did your company try to obtain a loan from a bank (2015-2017)?

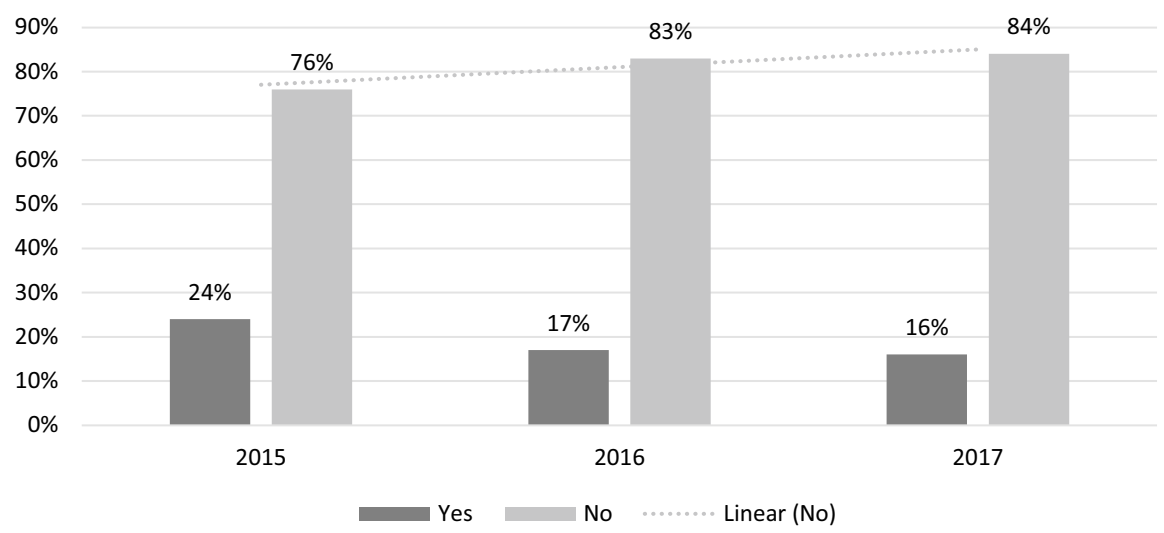

Source: SEBRAE (2017)

Fig. 11 Bank loan applications—Sample period: 2015-2017. Source: SEBRAE (2017)

Figure 11 presents the responses of SMEs who were asked about whether in the past 6 months they attempted to obtain a loan from a bank. In Brazil, 24\% of the companies did manage to apply for a loan in 2015 . It means that $76 \%$ of the SMEs did not manage to apply for a loan, which is consistent with prior empirical research on some countries in the European Union. ${ }^{53}$ The figure shows that the firms that actually applied for a loan has been declining since 2015. Moreover, the loan applicants surveyed in the SEBRAE study indicated that a number of factors influenced whether or not to apply for a loan. First, $51 \%$ of firms responded that they were no longer attracted to taking out a loan. Second, a significant number of firms (39\%) cited that they do not need a loan. Third, a smaller number of firms reported that they did not like loans or paying high interest rates.

Consistent with our expectations, we find, between 2015 and 2017, a significant number of SMEs did not apply for a loan because of possible rejection. In summary, these results confirm previous studies on borrower discouragement in developing economies, such as Brazil. ${ }^{54}$

\subsection{Support for Loan Granting and Guarantee Programs}

Before we address alternative forms of financing for SMEs, we pose the more fundamental question about the growing concern that SMEs need guarantees to access credit. With stringent collateral and guarantee requirements, SMEs are likely to have

\footnotetext{
53 Mac an Bhaird et al. (2016); Mol-Gomez-Vazquez et al. (2018).

54 Chakravarty and Xiang (2013).
} 


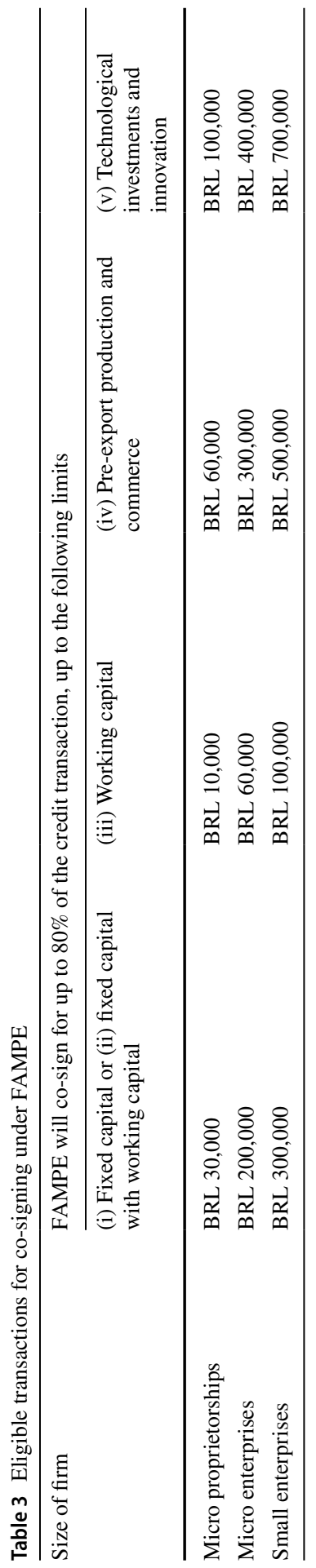


Table 4 Guarantees granted by FAMPE (2015/2016/2017). Source: SEBRAE

\begin{tabular}{|c|c|c|c|c|c|c|}
\hline \multirow[t]{2}{*}{ Year } & \multirow[t]{2}{*}{ Firm size } & \multicolumn{3}{|c|}{ Guarantees per industry } & \multirow[t]{2}{*}{ Total per firm size } & \multirow[t]{2}{*}{ Total per year } \\
\hline & & Commerce & Services & Manufacturing & & \\
\hline \multirow[t]{3}{*}{2015} & Micro proprietorship & 20 & 32 & 17 & 69 & 14,460 \\
\hline & Micro enterprise & 239 & 323 & 116 & 678 & \\
\hline & Small enterprise & 6515 & 3944 & 3254 & 13,713 & \\
\hline \multirow[t]{3}{*}{2016} & Micro proprietorship & 7 & 14 & 4 & 25 & 9741 \\
\hline & Micro enterprise & 145 & 249 & 31 & 425 & \\
\hline & Small enterprise & 4470 & 2870 & 1951 & 9291 & \\
\hline \multirow[t]{4}{*}{2017} & Micro proprietorship & 61 & 66 & 17 & 144 & 15,499 \\
\hline & Micro enterprise & 304 & 256 & 71 & 631 & \\
\hline & Small enterprise & 7893 & 4148 & 2683 & 14,724 & \\
\hline & Totals & 19,654 & 11,902 & 8144 & 39,700 & \\
\hline
\end{tabular}

Table 5 Total amounts guaranteed by FGI-2014, 2015, 2016. Source: BNDES (2017)

\begin{tabular}{|c|c|c|c|c|c|c|c|c|c|}
\hline \multirow[t]{2}{*}{ Type/size of borrower } & \multicolumn{3}{|c|}{$\begin{array}{l}\text { Total amount financed (in } \\
\text { thousand BRL) }\end{array}$} & \multicolumn{3}{|c|}{$\begin{array}{l}\text { Total amount guaranteed (in } \\
\text { thousand BRL) }\end{array}$} & \multicolumn{3}{|c|}{ No. of transactions } \\
\hline & 2014 & 2015 & 2016 & 2014 & 2015 & 2016 & 2014 & 2015 & 2016 \\
\hline Micro proprietorship & 366,559 & 79,546 & 2849 & 274,553 & 62,256 & 2020 & 2187 & 845 & 20 \\
\hline Microenterprise & 226,464 & 145,590 & 145,860 & 152,064 & 110,881 & 112,897 & 1208 & 1044 & 1453 \\
\hline Small enterprise & 149,057 & 100,304 & 269,010 & 103,905 & 71,949 & 202,889 & 458 & 426 & 851 \\
\hline Mid-size enterprise & 164,070 & 139,828 & 191,480 & 104,243 & 105,848 & 134,680 & 369 & 396 & 236 \\
\hline Total & 906,150 & 465,268 & 609,199 & 634,765 & 350,934 & 452,486 & 4222 & 2711 & 2560 \\
\hline
\end{tabular}

Table 6 Guaranteed percentages (FGI-2014, 2015, 2016). Source: BNDES (2017)

\begin{tabular}{|c|c|c|c|c|c|c|c|c|c|}
\hline \multirow{2}{*}{$\begin{array}{l}\text { Guaranteed } \\
\text { percentage } \\
(\%)\end{array}$} & \multicolumn{3}{|c|}{$\begin{array}{l}\text { Total amount financed (in } \\
\text { thousand BRL) }\end{array}$} & \multicolumn{3}{|c|}{$\begin{array}{l}\text { Total amount guaranteed (in } \\
\text { thousand BRL) }\end{array}$} & \multicolumn{3}{|c|}{ No. of transactions } \\
\hline & 2014 & 2015 & 2016 & 2014 & 2015 & 2016 & 2014 & 2015 & 2016 \\
\hline 20 & 79,043 & 12,794 & 19,718 & 15,809 & 2559 & 3944 & 438 & 68 & 14 \\
\hline 30 & 52,097 & 10,032 & 19,354 & 15,629 & 3009 & 5806 & 101 & -6 & 14 \\
\hline 40 & 15,048 & 8130 & 8701 & 6019 & 3252 & 3480 & 18 & 12 & 7 \\
\hline 50 & 18,650 & 10,693 & 26,188 & 9325 & 5347 & 13,094 & 34 & 16 & 22 \\
\hline 60 & 21,041 & 9970 & 8435 & 12,625 & 5982 & 5061 & 41 & 8 & 21 \\
\hline 70 & 8574 & 1357 & 3414 & 6002 & 950 & 2389 & 12 & -1 & 5 \\
\hline 80 & 711,697 & 412,293 & 523,389 & 569,357 & 329,834 & 418,712 & 3578 & 2614 & 2477 \\
\hline Total & 906,150 & 465,269 & 609,199 & 634,766 & 350,933 & 452,486 & 4222 & 2711 & 2560 \\
\hline
\end{tabular}

Negative figures stem from the number of cancelations being greater than the number of completed deals 
few external funding options through traditional banking channels. In general, credit guarantee schemes are used to provide credit support in lieu of collateral granted by the SME and may be effective in reducing the risk premium charged and help them qualify for a loan under the bank's loan policy. ${ }^{55}$

In Brazil, two important guarantee programs provide support to SMEs. The main funds are: (i) SEBRAE's ${ }^{56}$ 'FAMPE' (Fundo de Aval às Micro e Pequenas Empresas, or Micro and Small Enterprise Co-Signer Fund); and (ii) BNDES ${ }^{57}$ 'FGI' (Fundo Garantidor para Investimentos or Co-Signer Fund for Investments). SEBRAE's FAMPE can serve as a co-signer for eligible borrowers. Active since 1995, it has co-signed with more than 260,000 SMEs and raised approximately BRL 11 billion (of which BRL 7.81 billion became the liability of the FAMPE). The fund participates in a variety of transactions, including fixed capital, working capital, pre-export production and commerce and technological investments and innovation. Note that FAMPE will co-sign for up to $80 \%$ of the amount of the total credit granted to SMEs, according to the limits noted in Table $3 .^{58}$

In order to gauge the importance of support between 2015 and 2017, a total of 39,700 guarantees were granted by FAMPE. Table 4 shows that the vast majority of those guarantees went to small enterprises, while a very small percentage (about 5\%) was granted to micro proprietorships and micro enterprises. In practice, the number of guarantees granted by FAMPE is not excessive relative to the total number of SMEs in Brazil. This also suggests that the smallest companies are more likely to be denied guarantees and have limited access to bank credit. However, the data show that the number of guarantees granted to firms in the commercial sector is more than double the number seen in the manufacturing industry.

Turning to BNDES' FGI, this fund also serves as a co-signer for eligible borrowers for bank credit. Tables 5 and 6 show FGI's total amount and total percentage guaranteed, respectively, from 2014 to 2016. Interestingly, FGI has been active since 2010 and has provided support to more than 24,100 beneficiaries in 31,200 credit transactions totaling approximately BRL 5.8 billion (of which BRL 7.81 billion became the liability of the FGI).

In summary, despite the importance of guarantees to a small segment of SMEs, denials made to borrowers across Brazil are likely to increase as the banking system becomes less competitive, and fewer firms have access to credit.

\footnotetext{
55 OECD (2006).

56 Serviço Brasileiro de Apoio às Micro e Pequenas Empresas, or the Brazilian Micro and Small Business Support Service, is a not-for-profit private organization. According to its website, SEBRAE's mission is 'promoting the sustainable and competitive development of small businesses'. See http://www. sebrae.com.br/sites/PortalSebrae/canais_adicionais/sebrae_english (visited on 13 July 2018).

57 Banco Nacional de Desenvolvimento Econômico e Social, or the Brazilian Development Bank. According to its website, the BNDES 'is the main financing agent for development in Brazil'. See https ://www.bndes.gov.br/SiteBNDES/bndes/bndes_en/Institucional/The_BNDES/ (visited on 13 July 2018).

58 Resolução CDN No. 276/2016.
} 


\subsection{Private Equity and Venture Capital}

Recent studies have suggested that alternative sources of financing may provide credit access to support economic development. For example, many private equity and venture backed companies completed IPOs on Bovespa, which collectively raised US\$ 2.29 billion between 2004 and $2006 .{ }^{59}$ It is worth noting that analysis of the trends after the financial crisis shows an increased demand for financing coupled with a stagnation of stock markets and a significant drop in the supply of private equity and venture capital in Brazil. A further difficulty is that the numbers show that Brazilian private equity (PE) investment financing of SMEs is very small compared to that of similar countries. If we look at the breakdown of investment over the last decade, we can spot some notable features: a decline in the number of deals and capital raised through IPOs or follow-on offerings.

However, despite the low levels, Fig. 12 illustrates that the PE and VC markets have experienced steady growth in the last few years. For example, the total amount committed by investors rose from BRL 63.5 BB in 2011 to 153.2 BB in 2015.

Figure 13 also shows that, if we focus on capital distributed to investors, there is an upward trend for the period between 2011 and 2015.

Similarly, only a small fraction of capital committed by venture capitalists is invested in smaller companies. Moreover, Fig. 14 shows that of the total committed by investors, only $3.5 \%$ is allocated to venture capital, while $96.5 \%$ is dedicated to private equity. Interestingly, Fig. 15 shows that a larger percentage $(60.4 \%)$ of the deals involve venture capital transactions.

In recent years, especially after the financial crisis in 2008 , the sector turned to $\mathrm{VC}$ and PE for alternative channels of financing. Figure 16 shows that 63 companies received investments as private equity, with an average investment of BRL 277 MM and a median investment of BRL $35 \mathrm{MM}$. As far as venture capital is concerned, 96 firms received investments of BRL $12 \mathrm{MM}$, on average, with the median investment being BRL $4 \mathrm{MM}$ (Fig. 17). When considering both private equity and venture capital deals together, 159 companies received investments, with an average investment of BRL 177 MM and a median investment of BRL 5 MM (Fig. 18).

Note that between 2013 and 2015, the number of deals (private equity and venture capital together) went from 186 in 2013, down to 101 in 2014, and back up to 159 in 2015, while the average investment was BRL 95 MM in 2013, BRL 132 in 2014, and BRL 177 in 2015, as demonstrated in Fig. 19.

Regarding the origin of committed capital, while the percentage of foreign capital decreased from 2011 to 2012 (from 54 to $49 \%$ ), there was a steady increase in the years of 2013 (55\%), 2014 (56\%), and 2015 (57\%). The percentages of domestic capital, on the other hand, went from $46 \%$ in 2011 to $49 \%$ in 2012 and experienced a decline in the years of 2013 (45\%), 2014 (44\%), and 2015 (43\%), as illustrated in Fig. 20.

In this section, we lay out the importance of SMEs in the economy and map out the potential sources of capital market financing in Brazil. The data suggest that

${ }^{59}$ De Lima Ribeiro (2007). 
Total capital committed by investors - in BRL BB

200.0

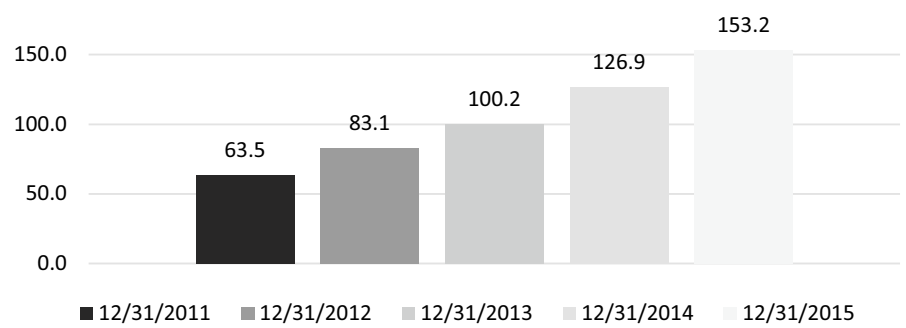

Fig. 12 PE and VC capital—total committed by investors (evolution)—BRL BB. Source: Associação Brasileira de Private Equity \& Venture Capital \& KPMG (2016)

Distributed to investors - BRL BB

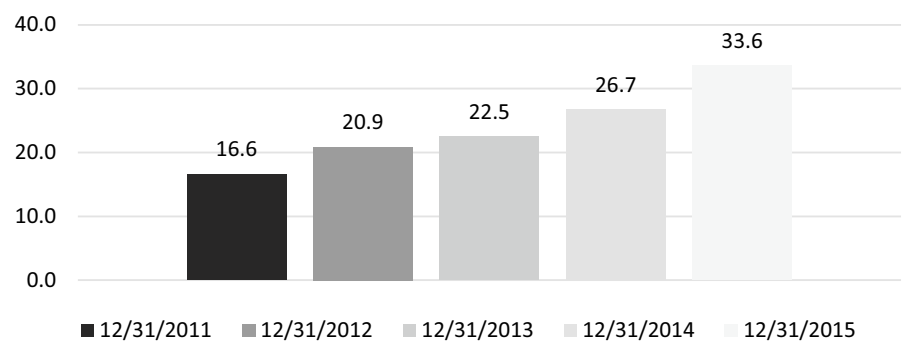

Fig. 13 PE and VC capital-total distributed to investors (evolution)—BRL BB. Source: Associação Brasileira de Private Equity \& Venture Capital \& KPMG (2016)

\section{Total capital committed by investors}

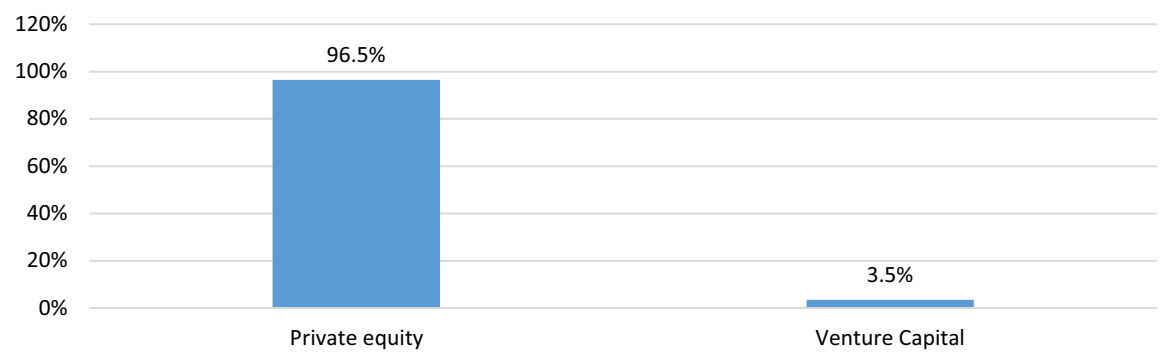

Fig. 14 PE and VC capital—\% of total committed by investors by type in 2015. Source: Associação Brasileira de Private Equity \& Venture Capital \& KPMG (2016)

banks' lending capacity shrank after the financial crisis, possibly due to higher risk aversion at a time when economic growth had slowed. In addition, equity financing, especially for the SME sector, declined in this period. In light of these findings, the SME sector faces increasingly limited access to financing, as it competes with larger 
$\%$ of deals

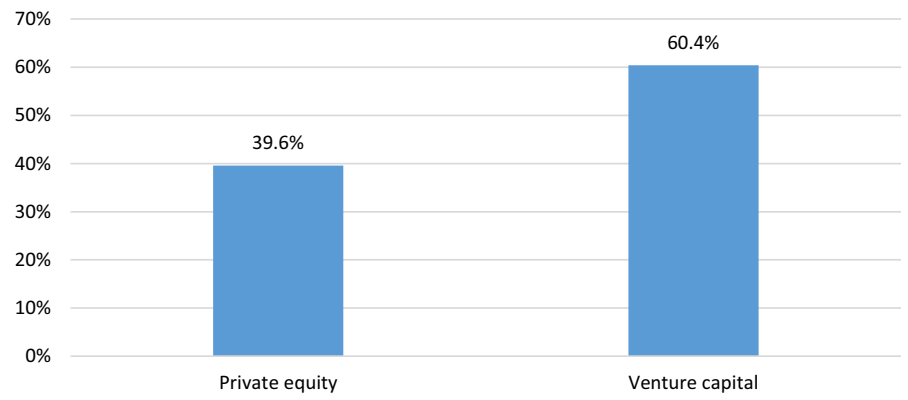

Fig. 15 PE and VC capital-percentage of deals in 2015. Source: Associação Brasileira de Private Equity \& Venture Capital \& KPMG (2016)

\section{Private equity}

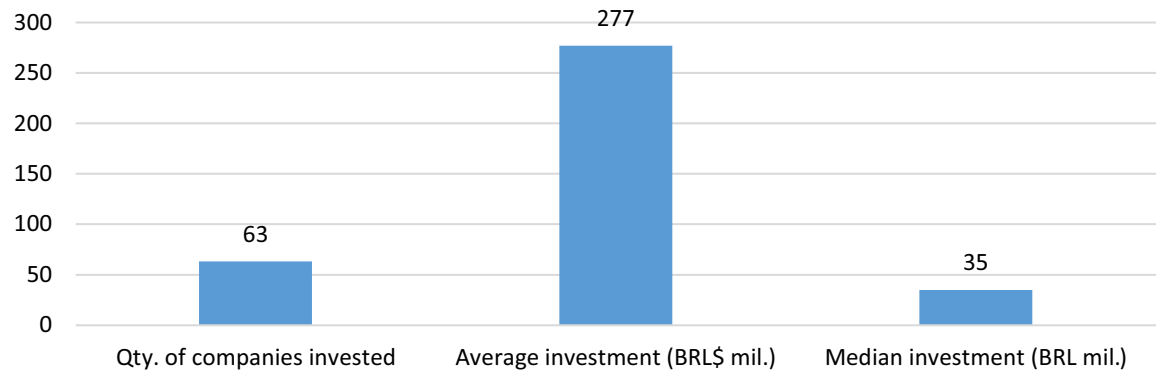

Fig. 16 PE—number of companies receiving PE investments and average investment 2015-BRL MM. Source: Associação Brasileira de Private Equity \& Venture Capital \& KPMG (2016)

\section{Venture capital}

120

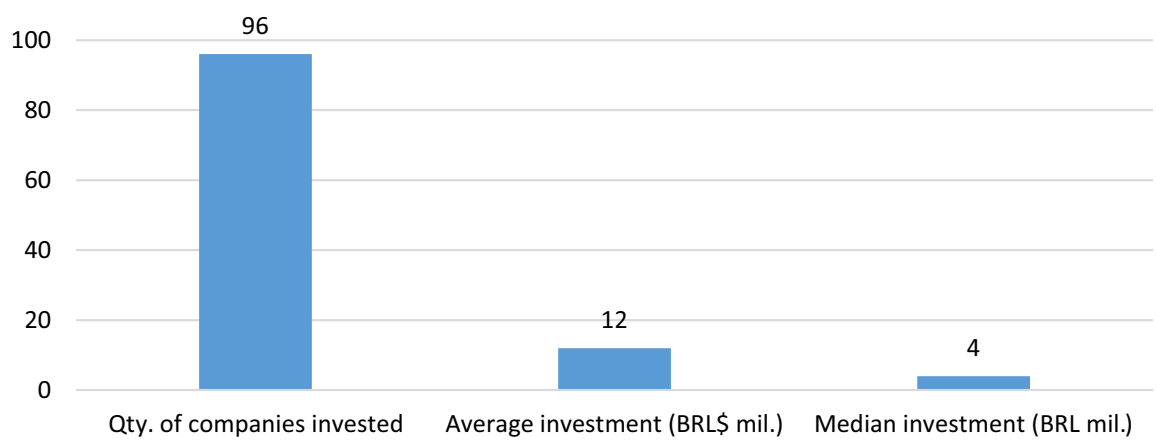

Fig. $17 \mathrm{VC}$-number of companies receiving VC investments and average investment. Source: Associação Brasileira de Private Equity \& Venture Capital \& KPMG (2016) 


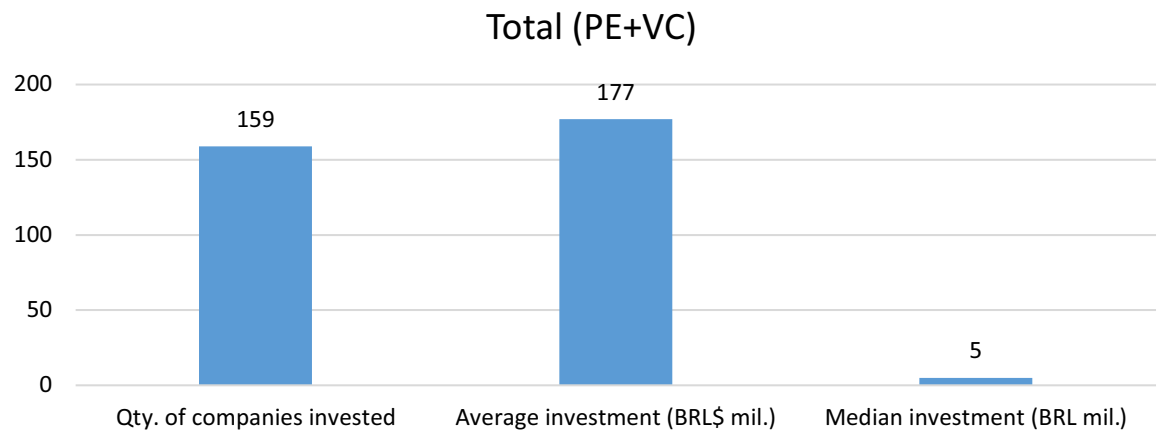

Fig. $18 \mathrm{PE}+\mathrm{VC}$-number of companies receiving investments (total of PE and VC) and average investment. Source: Associação Brasileira de Private Equity \& Venture Capital \& KPMG (2016)

\section{Evolution of PE/VC investments 2013-2015}

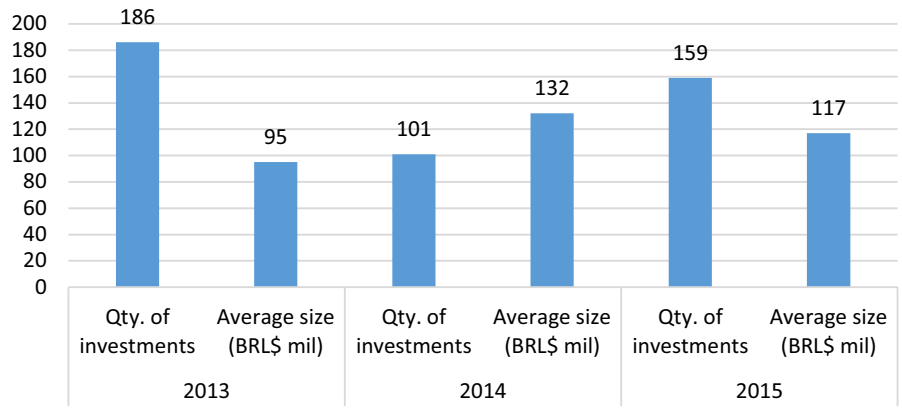

Fig. 19 PE and VC-evolution of investments (2013-2015). Source: Associação Brasileira de Private Equity \& Venture Capital \& KPMG (2016)

firms for a shrinking pool of resources. In the next section, we seek to provide an estimate of the size of the financing gap for SMEs in Brazil.

\section{SME Financing Gap in Brazil}

The earlier literature focused on the loan and equity supply trends in OECD countries and the effectiveness of diverse financial instruments to bridge the financing gap. ${ }^{60}$ The first empirical studies on the topic focused on the financing gap in emerging markets, examining the mismatch between potential supply and demand. ${ }^{61}$ More recently, researchers' attention has shifted to estimating the financing gap in European countries based on publicly available data. These studies seek to measure the

\footnotetext{
60 OECD (2014).

61 IFC (2013).
} 


\section{Origin of commited capital (foreign $\mathrm{x}$ domestic)}

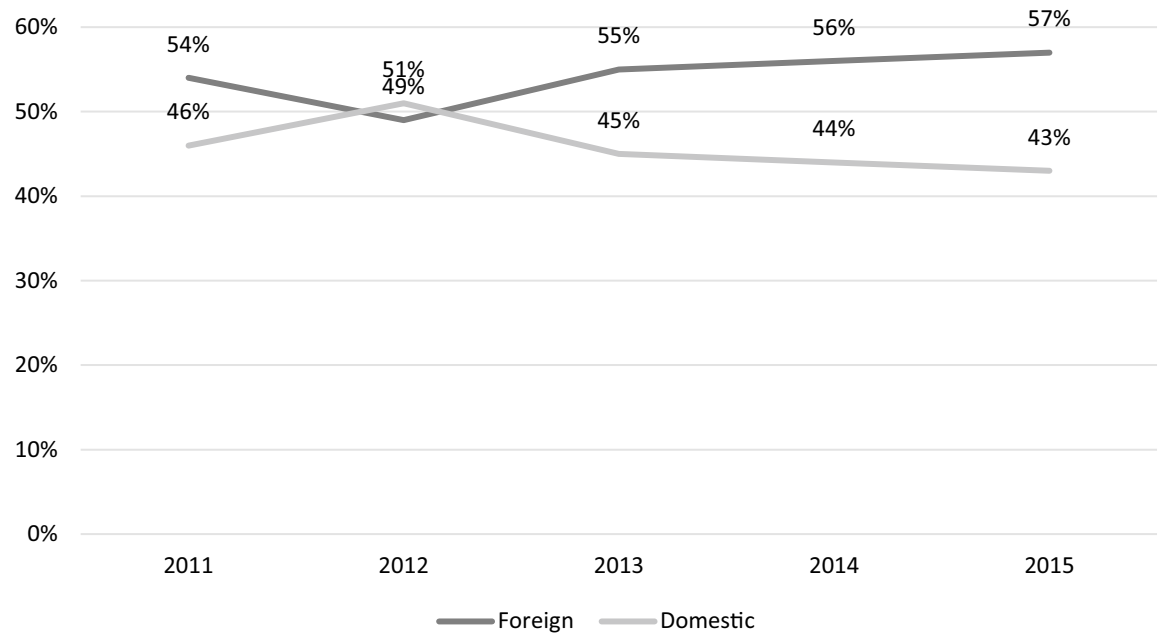

Fig. $20 \mathrm{PE}$ and VC-origin of committed capital (foreign vs. domestic). Source: Associação Brasileira de Private Equity \& Venture Capital \& KPMG (2016)

Table 7 Brazilian GDP (2014/2015/2016-BRL MM). Source: IBGE [see https://agenc iadenoticias.ibge.gov.br/media/ com_mediaibge/arquivos/7531a $821326941965 f 1483$ c85caca 1 1 f.xls (visited on 26 October 2019)]

\begin{tabular}{ll}
\hline Year & $\begin{array}{l}\text { Brazilian } \\
\text { GDP in } \\
\text { BRL MM }\end{array}$ \\
\hline 2014 & $5,778,953$ \\
2015 & $6,000,570$ \\
2016 & $6,266,895$
\end{tabular}

\section{Credit-to-GDP ratios (actual data) - Brazil - Credit from all sectors to private non-financial sector - \% and BRL MM}

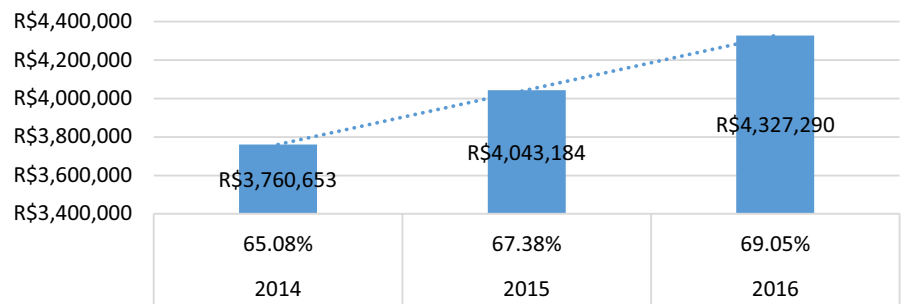

Fig. 21 Brazilian credit-to-GDP ratio (\%) and growth. Source: Banco Central do Brasil (2017)

supply and demand of credit and the factors preventing companies from acquiring adequate external financing. In this section, we assess the size of the financing gap in Brazil. 


\section{Total credit granted by banks - BRL MM}

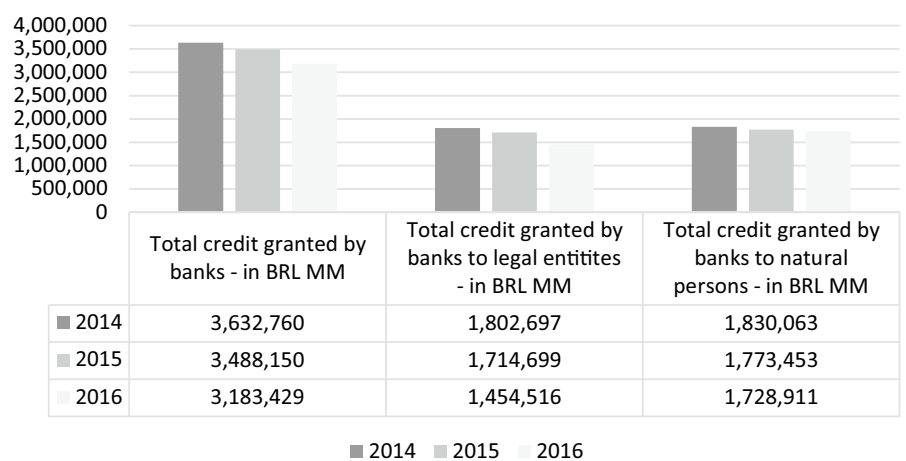

Fig. 22 Total credit granted by banks in Brazil-BRL MM. Source: Banco Central do Brasil (2017)

Table 8 Credit from other sources (capital markets)—in BRL MM. Source: Banco Central do Brasil (2017)

\begin{tabular}{llll}
\hline Year & $\begin{array}{l}\text { Total credit-in BRL } \\
\text { MM }\end{array}$ & $\begin{array}{l}\text { Bank credit (debt)—in BRL } \\
\text { MM }\end{array}$ & $\begin{array}{l}\text { Credit from other sources } \\
\text { (capital markets)—in BRL } \\
\text { MM }\end{array}$ \\
\hline 2014 & $3,760,653.66$ & $3,632,760.00$ & $127,893.66$ \\
2015 & $4,043,184.38$ & $3,488,150.00$ & $555,034.38$ \\
2016 & $4,327,290.82$ & $3,183,429.00$ & $1,143,861.82$ \\
\hline
\end{tabular}

Table 9 Total credit granted to legal entities-in BRL MM. Source: Banco Central do Brasil (2017)

\begin{tabular}{lcll}
\hline Year & $\begin{array}{l}\text { Credit from other sources (capital } \\
\text { markets)—in BRL MM }\end{array}$ & $\begin{array}{l}\text { Credit granted to legal enti- } \\
\text { ties-in BRL MM }\end{array}$ & $\begin{array}{l}\text { Total credit granted to } \\
\text { legal entities-In BRL } \\
\text { MM }\end{array}$ \\
\hline 2014 & 127,894 & $1,802,697$ & $1,930,591$ \\
2015 & 555,034 & $1,714,699$ & $2,269,733$ \\
2016 & $1,143,862$ & $1,454,516$ & $2,598,378$ \\
\hline
\end{tabular}

Table 10 Financing gap. Source: Banco Central do Brasil (2017), IBGE (2017) and SEBRAE (2014)

\begin{tabular}{llll}
\hline Description & 2014 & 2015 & 2016 \\
\hline Percentage of SMEs in banks active credit portfolio & $17.50 \%$ & $15.95 \%$ & $14.40 \%$ \\
Total credit granted to legal entities in Brazil-In BRL MM & $1,930,591$ & $2,269,733$ & $2,598,378$ \\
Total credit directed to SMEs_in BRL MM & 337,853 & 362,022 & 374,166 \\
Value added by SMEs & $27 \%$ & $27 \%$ & $27 \%$ \\
Credit ideally available to SMEs & $521,259.57$ & $612,827.91$ & $701,562.06$ \\
Financing GAP in BRL MM & $183,406.15$ & $250,805.50$ & $327,395.63$ \\
Financing GAP in \% & $54.29 \%$ & $69.28 \%$ & $87.50 \%$ \\
\hline
\end{tabular}




\section{Financing GAP in \%}

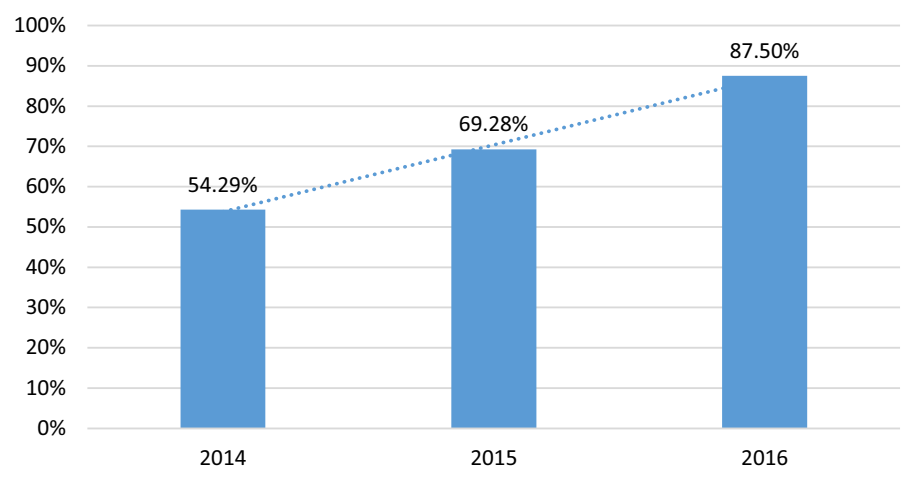

Fig. 23 Financing gap in $\%$

Financing GAP in BRL MM

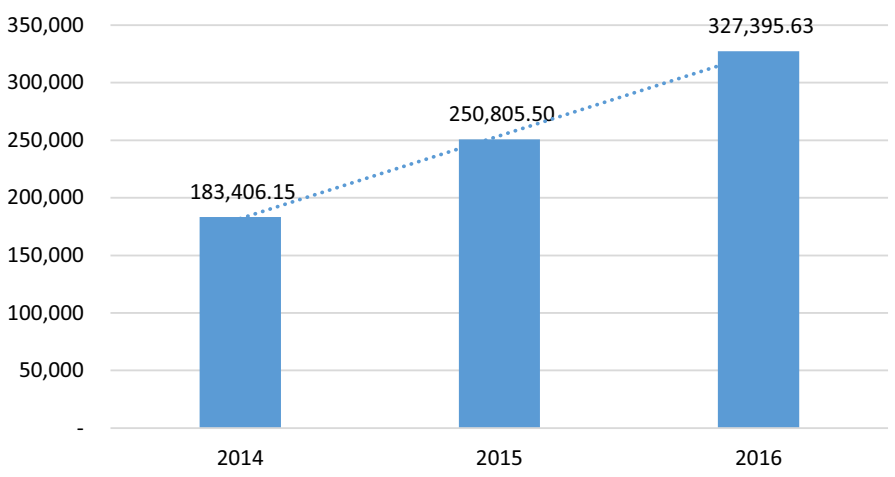

Fig. 24 Financing gap in BRL MM

\subsection{Assessing the Financing Gap}

In order to assess the size of the SME financing gap, we rely mainly on general information on credit, as provided by the Central Bank of Brazil, but also on other economic data made available by the Brazilian Institute of Geography and Statistics (IBGE-Instituto Brasileiro de Geografia e Estatística), a government-run statistical office, and the Brazilian Service to Support Micro and Small Enterprises (SEBRAE - Serviço de Apoio às Micro e Pequenas Empresas), a non-governmental organization that provides assistance to SMEs.

Moreover, information about the Brazilian GDP also came from the IBGE, which gathers and analyzes certain data related to the Brazilian economy. We obtained information on the Credit-to-GDP ratio, on the total credit granted by banks (including to SMEs), and on other credit raised in capital markets from the Central Bank of Brazil. 


\subsubsection{Credit-to-GDP Ratios}

According to the Central Bank of Brazil (2017), the credit-to-GDP ratio in Brazil is low, which reduces systemic risk, as well as the possibility of abrupt market corrections. Table 7 shows a summary of Brazilian GDP, which ranged from BRL 5778 MM in 2014, to BRL $6000 \mathrm{MM}$ in 2015, and to BRL $6266 \mathrm{MM}$ in 2016.

Note that the credit-to-GDP ratio in Brazil comprises all types of financing and reached $65.08 \%$ in 2014 (with a total of BRL 3.76 trillion), $67.38 \%$ in 2015 (with a total of BRL 4.04 trillion), and $69.05 \%$ in 2016 (with a total of BRL 4.32 trillion), representing steady growth (see Fig. 21).

\subsection{Supply, Demand, and Finance Gap Estimation}

As Fig. 22 shows, the total amount of credit granted by banks in Brazil was BRL 3.63 trillion in 2014, BRL 3.48 trillion in 2015, and BR 3.18 trillion in 2016, of which BRL 1.80 trillion (2014), BRL 1.71 (2015), and BRL 1.45 trillion (2016) were advanced to firms. The total amount of credit supplied by banks to natural persons was BRL 1.83 trillion in 2014, BRL 1.77 trillion in 2015, and BRL 1.72 in 2016.

To be sure, those amounts do not take into consideration the financing raised in capital markets (see Table 8). As a rule-of-thumb, financing raised in capital markets is directed to firms, not to individuals.

Thus, the total financing raised in capital markets should be added to the total credit obtained by legal entities in 2014, 2015 and 2016 (Table 9).

Recall that SMEs represent $27 \%$ of Brazilian GDP. The data show that the percentage of bank credit granted to SMEs was $17.5 \%$ in $2014,15.95 \%$ in 2015 , and $14.4 \%$ in 2016. As SMEs represented 27\% of Brazilian GDP between 2014 and 2016, the ideal percentage of credit granted to SMEs should mirror that amount. So, using the participation of SMEs in Brazilian GDP as a proxy, we are able to estimate the financing gap by subtracting the total credit granted to SMEs from the proxy (Table 10).

Confirming our expectations, the financing gap grew steadily between 2014 and 2016. Figure 23 reports that the SME financing gap in Brazil was 54.29\% in 2014, $69.28 \%$ in 2015 and $87.5 \%$ in 2016. We also observe in Fig. 23 that the financing gap reached BRL 183,406.15 MM in 2014, 250,805.50 in 2015, and BRL 327,395.63 in 2016.

In summary, the results illustrate that the loan gap ranged from $54.29 \%$ in 2014 to $87.5 \%$ in 2016 (Fig. 24). Importantly, the estimated financing gap appears to be similar to estimates available in earlier studies. Nevertheless, the data indicate that the financing gap in Brazil is much larger than that in other emerging markets. Thus, Brazilian investors are likely to find fewer funding opportunities among SMEs. 


\section{Conclusion}

In this paper, we investigate the challenges of SME financing in Brazil. In line with our predictions, we find that the financing gap in Brazil grew steadily between 2014 and 2016. These numbers are substantial, considering that our total estimated financing gap ranges from $54.29 \%$ in 2014 to $87.5 \%$ in 2016 . By providing an estimate of the sizable credit gap faced by SMEs, our paper complements the existing literature that seeks to identify the impact of measures designed to induce banks to extend more credit to SMEs.

Additionally, our analysis of the large equity gap faced by SMEs suggests that we also need to explore how to induce market participants to provide equity capital to high growth firms. This is particularly important in the context of the very low level of incentives for SMEs in Brazil to obtain venture capital or private equity financing. The effect of the recent decrease in equity capital will play an important role in the various growth strategies of innovative and high growth SMEs. Therefore, in order for SMEs to enhance their own growth, there is a need for technical assistance facilities financed by third parties to stimulate the investment by private equity finance. ${ }^{62}$

Our study reinforces evidence found in earlier studies on the problem of high bank interest rates and spreads. Three key issues need to be addressed. These relate to the need to amend and improve the law dealing with creditors' rights in order to reduce delinquency. Moving toward reduced levels of capital requirements that are closer to international standards will free up more capital that can be loaned to SMEs. It is important to note that, notwithstanding these issues, streamlining changes in Brazilian legislation would potentially reduce administrative costs and overheads, including, for example, labor legislation. Most pressing, perhaps, is the key priority that the Brazilian tax system needs an overhaul. However, this should comprise not only the taxation of SMEs, but the entire system, including financial institutions: reducing their operating costs would free more capital that could also be loaned to SMEs.

Another issue that needs to be addressed is the high concentration levels in the Brazilian banking market. The key issue in Brazil is a situation in which many borrowers are denied credit or receive a lower level of credit than they applied for. To be sure, this is not a uniquely Brazilian problem, as many small firms across Europe are experiencing higher rejection rates compared to recent years. Despite some recent gains, crucial issues for policymakers revolve around opening the market for competition, making it easier for new banks (including those with foreign capital) to enter the market. Key concerns include the ability to create special rules for marketplace lending and alternative forms of financing for SMEs. In the longer term, introducing new channels of finance for SMEs to seek loans will help companies fund research and development (R\&D) and innovative projects, thereby increasing the levels of capital available to them.

${ }^{62}$ Divakaran et al. (2014). 
Finally, it is worth noting that progress in improving access to financing for SMEs is hampered by the lack of collateral available. As indicated earlier, Brazil has two important guarantee programs in place that provide important support for some SMEs seeking access to loan capital. Although proposals have been made to expand the existing loan guarantee programs, to date, they have made little progress. Therefore, successfully expanding existing programs and creating new ones are of major importance to reducing the loan gap to SMEs in Brazil.

Open Access This article is distributed under the terms of the Creative Commons Attribution 4.0 International License (http://creativecommons.org/licenses/by/4.0/), which permits unrestricted use, distribution, and reproduction in any medium, provided you give appropriate credit to the original author(s) and the source, provide a link to the Creative Commons license, and indicate if changes were made.

\section{References}

Akerlof GA (1970) The market for 'lemons': quality uncertainty and the market mechanism. Q J Econ 84:488-500

Associação Brasileira de Private Equity \& Venture Capital \& KPMG (2016) Consolidação de dadosindústria de private equity e venture capital no Brasil. KPMG \& ABVCAP, São Paulo

Ayadi R, Gadi S (2013) Access by MSMEs to finance in the Southern and Eastern Mediterranean: what role for credit guarantee schemes? https://www.medpro-foresight.eu/system/files/MEDPRO\%2520T R\%2520No\%252035\%2520WP6\%2520Ayadi.pdf. Accessed 9 Feb 2019

Ayyagari M, Demirgüç-Kunt A, Maksimovic V (2011) How important are financing constraints? The role of finance in the business environment. World Bank Econ Rev 22:483-516

Banco Central do Brasil (2014) Relatorio de Economia Bancaria e Credito. Brasilia

Banco Central do Brasil (2017) Relatório de estabilidade financeira. Brasilia

BCG (2017) The mix that matters: innovation through diversity. https://www.bcg.com/publicatio ns/2017/people-organization-leadership-talent-innovation-through-diversity-mix-that-matters.aspx. Accessed 1 Sept 2019

Beck T, Demirguc-Kunt A (2006) Small and medium-size enterprise: access to finance as a growth constraint. J Bank Finance 30:2931-2943

Beck T, Demiguc-Kunt A, Martinez Peira MS (2011) Bank financing for SMEs: evidence across countries and bank ownership types. J Financ Serv Res 39:35-54

Belaisch A (2003) Do Brazilian banks compete? https://ssrn.com/abstract=879189. Accessed 9 Feb 2019

Berger AN, Udell GF (1995) Universal banking and the future of small business lending. https://ssrn. com/abstract $=1298316$. Accessed 9 Feb 2019

Berger AN, Udell GF (1998) The economics of small business finance: the roles of private equity and debt markets in the financial growth cycle. J Bank Finance 22:613-673

Berger AN, Klapper L, Martinez Peria MS, Zaidi R (2008) Bank ownership type and banking relationships. J Financ Intermed 17:37-62

BNDES-Banco Nacional de Desenvolvimento Econômico e Social (2017) Relatório da Administração do Exercício de 2016-Prestação de Constas Anual 2016. BNDES, Rio de Janeiro

Chakravarty S, Xiang M (2013) The international evidence on discouraged small businesses. J Empir Finance 20:63-82

Claessens S, Laeven L (2004) What drives bank competition? Some international evidence. J Money Credit Bank 36:563-583

Cole R, Sokolyk T (2016) Who needs credit and who gets credit? Evidence from surveys of small business finances. J Financ Stab 24:40-60

Conceição Canozzi O, Saraiva MV, Fochezatto A, Tulio M, França A (2018) Brazil's simplified tax regime and the longevity of Brazilian manufacturing companies: a survival analysis based on RAIS microdata. EconomiA 19:164-186

de Lima Ribeiro L (2007) High-growth SMEs and the availability of private equity and venture capital in Brazil. https://papers.ssrn.com/sol3/papers.cfm?abstract_id=1082438. Accessed 1 Sept 2019 
Divakaran S, McGinnis PJ, Shariff M (2014) Private equity and venture capital in developing countries: the role of technical assistance. https://openknowledge.worldbank.org/handle/10986/17714. Accessed 1 Sept 2019

European Economic and Social Committee (2017) Effectiveness of policies for SMEs. https://www. eesc.europa.eu/en/our-work/opinions-information-reports/opinions/effectiveness-policies-smes. Accessed 1 Sept 2019

Febraban-Federação Brasileira de Bancos (2015) Painel econômico e financeiro 2016

Fenwick M, McCahery J, Vermeulen EPM (2018) Fintech and the financing of SMEs and entrepreneurs: from crowdfunding to marketplace lending. In: Cumming D, Hornuf L (eds) The economics of crowdfunding: startups, portals, and investor behavior. Palgrave Macmillan, London, pp 103-129

Fiche ME (2015) Spread bancário no Brasil. Brasilia

Franco C, Sampaio B, Sampaio GR, Vaz P (2017) Tax compliance costs and employment in SMEs: evidence from a size-dependent policy in Brazil. https://papers.ssrn.com/sol3/papers.cfm?abstract_ id=2969041. Accessed 1 Sept 2019

Han L, Fraser S, Storey DJ (2009) Are good and bad borrowers discouraged from applying for loans? Evidence from US small business credit markets. J Bank Finance 33:415-424

Harhoff D, Korting T (1998) Lending relationships in Germany: empirical evidence from survey data. J Bank Finance 22:1317-1353

IBGE_-Instituto Brasileiro de Geografia e Estatística (2014) Pesquisa de inovação. Instituto Brasileiro de Geografia e Estatística-IBGE, Rio de Janeiro

IBGE-Instituto Brasileiro de Geografia e Estatística (2017) Demografia das empresas: 2015. Instituto Brasileiro de Geografia e Estatística-IBGE, Rio de Janeiro

IFC (2010) Scaling-up SME access to financial services in the developing world. Financial inclusion experts group, G20 Seoul Summit. http://documents.worldbank.org/curated/en/669161468140035 907/pdf/948300WP0Box385443B00PUBLIC00ScalingUp.pdf. Accessed 1 Sept 2019

IFC (2013) Small and medium enterprise finance: new findings, trends and G-20/global partnership for financial inclusion progress. https://www.gpfi.org/sites/gpfi/files/documents/SME\%20Finance $\% 20$ New\%20Findings\%2C\%20Trends\%20and\%20G20\%20GPFI\%20Progress.pdf. Accessed 1 Sept 2019

IFC (2017) MSME financing gap: assessment of the shortfalls and opportunities in financing micro, small and medium enterprises in emerging markets. https://www.smefinanceforum.org/sites/default/files/ Data\%20Sites\%20downloads/MSME\%20Report.pdf. Accessed 1 Sept 2019

IMF (2019) Fintech in Latin America and the Caribbean: stocktaking. https://www.imf.org/en/Publi cations/WP/Issues/2019/03/26/Fintech-in-Latin-America-and-the-Caribbean-Stocktaking-46677. Accessed 1 Sept 2019

Info/World Bank (2016) Growth entrepreneurship in developing countries: a preliminary literature review. https://www.infodev.org/infodev-files/growth_entrepreneurship_in_developing_countries__a_preliminary_literature_review_-_february_2016_-_infodev.pdf. Accessed 9 Feb 2019

Kgoroeadira R, Birk A, van Stel A (2018) Small business online loan crowdfunding: who gets funded and what determines the rate of interest? Small Bus Econ 52:67-87

Kon Y, Storey DJ (2003) A theory of discouraged borrowers. Small Bus Econ 21:37-49

Lopes de Silanes F, McCahery JA, Schoenmaker D, Stanišić D (2015) The European capital markets study: estimating the financing gaps of SMEs. http://www.dsf.nl/wp-content/uploads/2015/08/Europ ean-Capital-Markets-Study_2015_FINAL-15-7.pdf. Accessed 1 Nov 2015

Love I, Martinez Peria MS (2015) How bank competition affects firms' access to finance. World Bank Econ Rev 29:413-448

Mac an Bhaird C, Vidal JS, Lucey B (2016) Discouraged borrowers: evidence from Eurozone SMEs. J Int Financ Mark Inst Money 44:46-55

McCann P, Ortega-Argilés R (2016) Smart specialization, entrepreneurship and SMEs: issues and challenges for a results-oriented EU regional policy. Small Bus Econ 46:537-552

Melo P, de Hoyos Guevara AJ, Martins Corrêa R, Valentim DSG (2015) Innovation performance in Brazil—what is missing? From the perspective of micro and small and technology-based firms. RISUS J Innov Sustain 6:73-96

Mol-Gomez-Vazquez A, Hernandez-Canovas G, Koeter-Kant J (2018) Bank market power and the intensity of borrower discouragement: analysis of SMEs across developed and developing European countries. Small Bus Econ 53:211-225

OECD (2006) The SME financing gap: theory and evidence, vol 1. OECD Publishing, Paris 
OECD (2014) SMEs and the credit crunch: current financing difficulties, policy measures and a review of literature. OECD J Financ Mark Trends 2013:2

OECD (2018) Financing SMEs and entrepreneurs 2018: an OECD scoreboard. OECD Publishing, Paris

OECD (2019) Financing SMEs and entrepreneurs 2019: an OECD scoreboard. OECD Publishing, Paris

Padilla AJ, Pagano M (1997) Endogenous communications among lenders and entrepreneurial incentives. Rev Financ Stud 10:205-236

Petersen MA, Rajan RG (1995) The effect of credit market competition on lending relationships. Q J Econ 110:407-443

SEBRAE—Serviço Brasileiro de Apoio às Micro e Pequenas Empresas (2014) Participação das micro e pequenas empresas na economia brasileira. SEBRAE, Brasilia

SEBRAE-Serviço Brasileiro de Apoio às Micro e Pequenas Empresas (2017) Relatório especial—o financiamento das MPE no Brasil. SEBRAE, Brasilia

Tabak BM, Fazio DM, Cajueiro DO (2010) The effects of loan portfio concentration on Brazilian banks' return and risk. http://bibliotecadigital.fgv.br/ocs/index.php/sbe/EBE10/paper/viewFile/2260/1160. Accessed 1 Sept 2019

Usman A, Beck T, McDaniel C, Schropp S (2016) Filling the gap: how technology enables access to finance for small-and medium-sized enterprises. Innovations 10:35-48

Publisher's Note Springer Nature remains neutral with regard to jurisdictional claims in published maps and institutional affiliations. 